Paper accepted as: Stojanovic, T. A., and K. Gee (2020). Governance as a framework to theorise and evaluate marine planning. Marine Policy. https://doi.org/10.1016/j.marpol.2020.104115

\title{
Governance as a framework to theorise and evaluate marine planning.
}

Tim Stojanovic ${ }^{1}$, Kira Gee ${ }^{2}$

\begin{abstract}
:
Marine Planning seems to offer promise to integrate oceans governance with a prospective approach to sustainability, most distinctively through the process of creating a spatial strategy contained in a marine plan, hence 'marine spatial planning'. This paper will show that in order to understand whether marine planning really is leading towards sustainability, recourse to governance theory will be required. Governance theory can provide principles or a theoretical framework for marine planning systems. It can also inform practicable planning, particularly in the phase of setting evaluatory criteria - a phase that many policy analysts consider should logically proceed the implementation of marine plans themselves- but also in broader questions of institutional design. Yet researchers and practitioners are faced with a situation in which there a multiple, competing approaches to governance from which to choose, some of which were developed in terrestrial contexts, raising questions about their applicability to the marine environment. This paper outlines five key major theoretical approaches for governance and reviews analytical debates and empirical findings about marine planning using those approaches. The core question of this study is which theoretical approaches offer the most traction for evaluating MSP and why?
\end{abstract}

Keywords: oceans, good governance, ecosystem approach, multi-level governance, modes, marine spatial planning

1 Introduction: Governance, Institutions and Planning for Oceans ............................................. 2

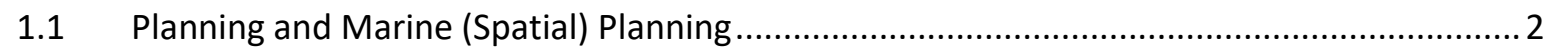

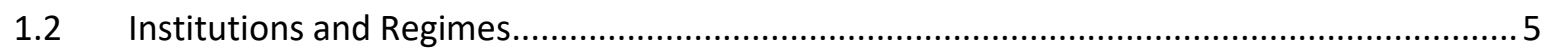

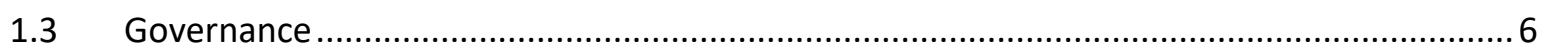

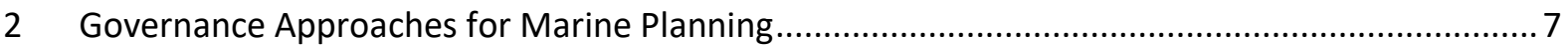

$2.1 \quad$ Ecosystem Approach, Ecosystem-Based management …..............................................

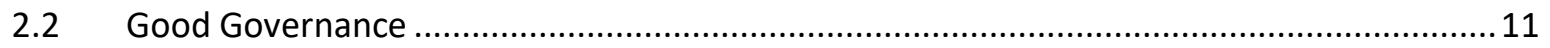

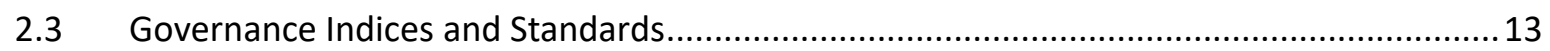

2.4 Modes of Governance (Collaborative, Networked, Adaptive, Transformative) ...................... 15

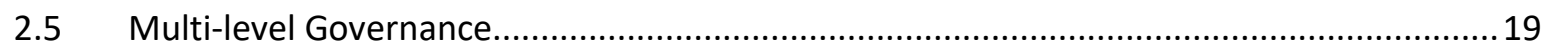

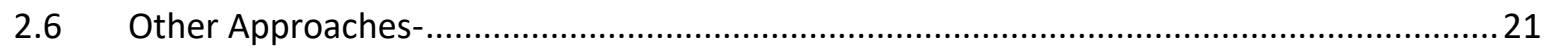

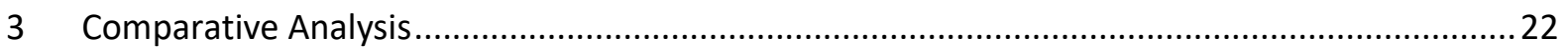

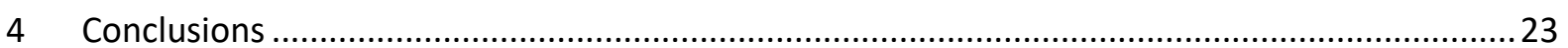

[184 References]

\footnotetext{
${ }^{1}$ School of Geography and Sustainable Development (Marine and Coastal Environment team) and Scottish Oceans Institute, University of St Andrews, KY16 9AL, Scotland, UK. Email: tas21@st-andrews.ac.uk

${ }^{2}$ Human Dimensions of Coastal Areas, Helmholtz Zentrum Geesthacht, Max-Planck-Str. 1, D-21502 Geesthacht, Germany.
} 


\section{INTROduCTION: GOVERNANCE, INSTITUTIONS AND PLANNING FOR OCEANS}

Governing the oceans involves a great array of organisations and issues. Simply describing them is an encyclopaedic task [1] [2] [3] [4] [5]. Beyond describing, scholars seek to 'theorise' how governance works in order to 'abstract' individual examples and compare them; analyse to explain why governance leads to certain patterns or outcomes; and evaluate whether forms of governance are leading to a better world. Multiple approaches have been developed to achieve this, and scholars argue about which are most effective. This paper presents a comparative perspective on governance and planning. Any given approach might be developed by an analyst into a theoretical framework which structures their inquiry into marine spatial planning. This works like a conceptual schema which "identifies the relevant elements and general relationships needed for analysis" [6] p.9. .

Marine spatial planning as an idea first developed in the 1970s and has seen widespread applications only since the 2000s [7], and is therefore relatively recent compared to terrestrial urban and regional planning, with the earliest national Town Planning legislation dating to 1909 in the UK. There are questions about Marine Planning's theoretical foundations, unresolved differences in how it is interpreted; and difficulties in evaluating its contribution to sustainability. Evaluating the contribution to sustainability involves reviewing the grand aspirations of MSP to deliver "thriving maritime economies, fewer conflicts and improved status of marine ecosystems" [8] p.417. Before considering how different perspectives on governance can support evaluation in marine planning, it will be necessary to 'clear a path' by being explicit about the debates in the literature concerning the use of some key terms. Planning, Institutions and Governance are core concepts which are contested or often used imprecisely, yet commonly feature in the context of MSP. This introductory section will present a variety of positions available- without setting precise definitions- and show how these assumptions frame research on the sustainability of the oceans.

\subsection{Planning and Marine (SPatial) Planning Planning Theory and History}

The idea of planning evokes a notion of deliberate action, oriented towards the future, to solve problems or create better places. Today many types of planning exist concurrently, such as land use planning, regional development planning, urban planning or spatial planning. Terms are not always sharply delineated, and certain terms preferred in different jurisdictions or national cultures. Landuse planning developed from a tradition of thought dating back to the ideas about civic design for urban spaces. The fields of Planning Theory and Planning History trace the development of ideas about planning practice and the role of the planner. They characterise several of phases of thought ${ }^{3}$ in different traditions, with an increasing diversity of approaches from the 1950s to the present day [9] [10]. A significant development is the emergence of rational, systematic planning (1960s-) which aims to conduct planning for control of development and provide technical analysis to support land use planning, based mainly on expert input. However, a range of critiques have highlighted limitations of 'expert knowledge' [11] [12] and argued for more democratic and participatory approaches both on ethical grounds and for reasons of effectiveness. Nevertheless, contemporary planning practice still engages with technical tasks such as infrastructure development and development of comprehensive regional strategies, and many contemporary instances of marine planning might be categorised in the

\footnotetext{
${ }^{3}$ Space does not permit detailed consideration of planning theories- readers may consider other key terms such as 'Incremental', 'Reflexive', 'Transactive', 'Phronetic', 'Advocacy' planning, and 'planning as design'
} 
rational systematic mode [13]. Environmental planning (1980s-) [14] reflects how the goal of sustainable development became (legally) mandated within many planning systems. In many planning systems, planners concurrently developed processes to engage communities and interest groups to identify goals and practices for sustainability. Collaborative (or communicative) planning (1990s-) takes this one step further by casting the planning professional as the facilitator of co-ordination [15] with an aspiration to inculcate positive change. In response to the critiques of top-down, expert led planning, this argues for processes of interaction between planners and other stakeholders, but one which carefully attends to the quality of these interactions and the ability to genuinely collaborate [16]. In Fuzzy planning (2000s-), the role of the planner is to help deal with differences in motivations and perceptions between participants [17], an emphasis which seems to be a response to increasingly pluralistic western societies and the complexity of contemporary sustainability problems.

Some planning theorists see the development of these ideas as shifts in dominant paradigms - they certainly present contrasting visions about what a planner should do and what planning might achieve. Other planning theorists argue that certain insights to be gained from each theory.

\section{Spatial Planning, Zoning and Co-location}

The ' $S$ ' in MSP can be related to the paradigm of 'Spatial planning' which developed in 1980s [18] [19]. This represents a shift in emphasis towards strategic planning, based on the need to integrate planning with other kinds of strategies in order to pursue sustainability. The vision of spatial planning includes ecological and economic objectives, as well as creating improved living conditions [19] [20]. During that time, spatial planning was seen in contrast to the perceived inflexibility of planning systems which were deemed to be fixated on designating spaces for different kinds of urban uses- for example housing, retail or commerce. Instead, spatial planning considers networks of interactions at a broader scale between different city regions and their hinterlands [21]. This kind of notion of a spatial vision for the land is understood rather differently in contemporary MSP which aims to minimise spatial conflicts whilst maximising the benefits from defined sea areas. Achieving these aims relies on the characterisation of the biophysical environment and subsequent analysis of human uses in a marine area, and is usually coupled with a regulatory approach that guides spatial development. Understood like this, MSP represents a rational-administrative approach to spatial planning driven by a functional perspective of the sea [22] [23]. It also has a particular perspective on the sea as a physical space which can be structured according to different demands and apportioned to different uses in the pursuit of socio-economic goals such as 'blue growth' and ecological objectives for marine ecosystems.

The idea of allocating marine space to achieve 'optimised' patterns of use is linked to zoning, or the use of area designations to guide activities or uses. This is a major contemporary debate within the MSP literature. Marine Zoning has proponents from conservation and development perspectives [24] [25] [26] [27] as it has been argued to align with a strong sustainability approach where marine planning includes the development of a zoned network of marine protected areas. Zoning has also been argued to provide clarity for developers in busy seas. In contrast, others argue that a reliance on zoning could generate new pressures via displacement of effort [28]; that zoning does not well account for maritime sectors, such as recreation, pelagic fishing or shipping which have locations which are relative to the water column rather than the seabed [29]; and that it can lead to compartmentalisation of activities that is neither desirable or sustainable given potential for colocation, multi-use and the nature of environmental gradients in the sea [30] [31]. Indeed a multi-use approach recognises the heterogeneity of options in mixing activities space and time to maximise synergies, though this is often dependent on careful prior planning and design to accommodate other uses [32].

\section{Marine Spatial Planning and Sea Use Management}

Marine planning systems are developing with the background history of terrestrial planning. But they also have their own heritage, as the antecedents of marine planning were early 1970/80s exercises in 
sea-use planning [33] [34] [35]. These initiatives reflected the newly extended jurisdictions of coastal nations over the Exclusive Economic Zone; the rise of new technologies and zoning for certain sectors such as offshore oil and gas; the environmental priorities of the age such as marine dumping and industrial pollution; and increasing potential for inter and intra sectoral conflicts between users in developed sea regions such as the North Sea and East Asia [36] $]^{4}$. This did not at this time lead to dedicated programmes of marine planning, but was rather reflected in new types of integrated policy analysis, departmental collaboration and impact assessment within government. It was also the starting phase of what has now developed into broad collaborative strategies for regional seas under the United Nations Environment Programme and other initiatives [37] [38]. Although conservation focussed, Zoning of the great barrier reef marine park in the late 1970s is often cited as an early example of large scale implementation of marine planning [39]. Douvere and Ehler [40] trace the first developments of comprehensive marine plans in North West Europe and China, and highlight the importance of measures beyond marine plans for governing marine space.

Kidd and Ellis [41] argue that marine planning has largely developed in isolation from terrestrial planning theory, but that national traditions of planning have varyingly influenced marine planning according to the context. In Germany for example, marine spatial planning is enabled by an amendment of the Federal Spatial Planning Act, extending the existing regulatory approach (including categories of area designations) to the sea, while in Sweden, the developing marine plans are set to provide strategic guidance only, in line with an overall approach to planning that is less prescriptive. Despite these different traditions, most approaches to MSP have commonalities with the concerns of terrestrial planning to control development and reduce environmental impacts related to "the externalities of unregulated development" [41] (p.52). The importance of global marine scientific discourses (including global marine assessments) is cited as another reason why scientific and technical rationalities are predominant in marine planning. For these reasons, marine planning is most associated with rational-systematic paradigm of planning [42]. The systematic approach seems to offer practicable guidance for those involved in implementation [43]. Concerning the ' $S$ ' in MSP, planning analysts have shown that core ideas from spatial planning, (such as spatial visions, economic and ecological goals), have been implicit in MSP attempts to organise marine space and inclusion of wider policy objectives [44]. Belgian and Dutch approaches to MSP with their broad designs and spatial visions are exemplars of this kind of thinking- for example the Belgian plan for the North Sea drew upon a range of six spatial visions based upon 'relaxed, natural, rich, playful, mobile or sailing' seas [45]. Furthermore, a comparison of German and UK MSP, finds evidence in latter for a collaborative approach [46], arguably drawing on the tradition of environmental or collaborative planning. At the same time, planning theory has also developed critiques of the contemporary practice in MSP. A lot is to be learned from the experience of terrestrial planning about issues, such as dealing with democratic deficit, for example [47]. Drawing on the perspectives of collaborative, phronetic and advocacy planning, contemporary marine planning has been critiqued as socially regressive in failing to consider social justice implications of marine developments, and lessons from terrestrial practice to develop a more pluralistic approach with grassroots engagement [48]. Other theorists argue that greater innovation is required in planning theory to fit with context of the oceans, particularly an understanding of spatiality which reflects the porous, fluid and mobile nature of marine space $[13]^{5}$ [49] [50]. A considerable grey literature is beginning to develop as marine planning professionals themselves debate these and other issues. ${ }^{6}$

\footnotetext{
${ }^{4}$ Another early example of sea use planning was the US state of Hawaii
}

\footnotetext{
6 These include e-newsletters of international networks such as Marine Ecosystems and Management https://meam.openchannels.org/, Planning Associations and Supranational bodies such as the European Union
} 
Returning to paradigms of planning theory, this provokes profound reflection on purpose and objectives of marine planning. Yet the great variety of conceptualisations presents a flux of ideas upon which to build. Making a highly simplified summary, one can distinguish between those theories which envisage a rather humble future for planner or planning team, placing them as one activist for broader processes of cultural change [51]; or one which seeks to provide stronger justification for planners and plan making, albeit as co-producers of knowledge with others [52] [53]. In contradistinction to contemporary planning theory, the practice of marine planning is characterised by the latter discourse - possibly because it is in its early phases of development, or possibly because of the distinctive nature of humanity's interactions with the oceans [54].

\subsection{InSTITUTIONS AND REGIMES}

If Governance is used as a frame of analysis, who or what is doing governing? Whereas in the framework of ocean and coastal planning and management, one might refer to a 'planner' or 'manager' and their organisation along with other stakeholders, in the framework of Governance, the referent often becomes the 'institutions' of governance, which are 'steering' the planning. Indeed, the issue of institutional design for the oceans has been discussed independently of the notion of planning, with arguments for ocean focussed ministries or commissions within government to prioritise marine issues [55] [56] [57] [58]; studies of the role of legal mandates or executive orders in influencing the integration of marine policy [59] [60]; or analysis of mechanisms to integrate different sectors and scales of jurisdiction [61] [62]. Marine Planning has been highlighted as a key tool to help achieve the latter goal [63] [64]. Using the term institutions, brings into consideration a much wider range of actors or influences which might affect the planning.

However, there are some major intellectual challenges to deploy the term 'institution'. There are many working definitions of institutions used across a range of disciplines [6] [65] [66] [67]. This is notwithstanding the fact that the term 'Institution' may be used by authors in a somewhat imprecise or general way. Sometimes, institutions are closely associated with an individual organisation and its accompanying structures (a more 'formal' definition institutions, such as is used in fields of resource management, policy studies, or international relations). At other times, institutions refer to processes and structures across a range of governing entities (a more sociological definition of institutions). A review of definitions shows that a study of institutions could variously focus upon the: Actors, Actions, Constraints, Norms, Incentives, Interactions, Organisations, Procedures, Rights, Rules, or Strategies. This is a very broad range of entities, and presents a challenge to operationalise the concept in empirical research and is potentially a confusing factor in reporting findings.

The field of International Relations presents an alternative, narrower concept of 'regimes' as a more specific term [68] [69] which reformulates many ideas implicit in focusing on institutional aspects. Regimes denote a special sub-set of circumstances where legal drivers have given rise to planning and management arrangements with certain institutional designs and regulatory procedures within a specific field. Related to this conceptualisation is the recognition that policymaking bodies are particular kinds of institution, which are explicitly committed to influencing other institutions. There is a focus on the more 'formal' aspects of institutions, as opposed to broader 'sociological' framings.

Many working definitions of institutions may be valid. However, a certain formulation may serve a particular purpose, but may also obscure other aspects. Probably the strength of the term institutions is to provide an analytical lens which can include a very broad range of influences, causes or reasons

Marine Spatial Planning Platform https://www.msp-platform.eu/ , Consultancies, and Government Agencies position papers e.g. http://www.abpmer.co.uk/services/marine-planning. 
about how governing is done. This is well illustrated when considering how marine planning is evaluated. Taking a 'planning' perspective may focus evaluation on plan-making, plan contents, outputs and outcomes - for example whether a plan policy 'achieved its goals' (such as increase in Megawatts output of renewable energy from offshore windfarms; or targets to reduce the noise pollution impacts of development on wildlife); was consistent with the principles of the framing law; or whether stakeholders 'approve' of the plan, or how many attended consultation events. Whilst these assessments are not unimportant, they do not really get at why planning is or is not effective. When planning is theorised in the context of governance and institutions, it provides an opportunity to undertake different kinds of evaluation [70]. These allow assessment of the institutional arrangements: what was it about the planning approach or planning culture, that affected the outputs and outcomes of the planning process?

\subsection{GOVERnANCE}

Up to the 1990s, the dominant trend was to refer to the 'planning' and 'management' of the oceans [71]. 'Governance' is a broader term which can be understood as 'how power is directed to enable or constrain human action'. The Oxford English Dictionary traces the development of the term from the thirteenth century French word Governaunce referring to exercise of political power or rule, from comes the which definition "Controlling, directing, or regulating influence". Bevir [72] defines governance as "all processes of governing whether undertaken by a government, market or network, over...formal or informal organisation or territory, whether through laws, norms, power or language" (p.1) whilst Evans [73] offers the definition "the purposeful effort to manage, steer or control sectors or facets of society in certain directions" (p.3). Governance as a framework better accounts for contemporary realities such as: the evolution of government and changing role of the state in developed western bureaucracies and other nations; the variety of sectors and interests in the marine environment; and the contributions made by different groups and organisations- particularly the increased participation of the role of private and voluntary sectors [74] [75] [76]. For example, in MSP, and more widely, there has been a rise in government administrations' use of soft policy instruments and management by consultation [77]. Olsen et al. [78] review considerable formal and information consultation in Belgium, Norway and US MSP, to varying degrees. Also non-state actors, such as NGOs have been highly influential in lobbying for particular forms of marine planning [79]. Another way to summarise this argument is to say that governance is a term which offers the best explanatory power to understand what is going on when marine planning is being done. It also highlights that marine planning often operates in parallel with other systems of management, regulation and assessment, although these can be understood as part of a broader marine planning 'system'.

Whilst governance is a more abstract term than planning and management, it does not supplant consideration of planning, management, policy or regulation. Rather it offers a different analytical perspective. For example, Osterblom and Folke [80] analyse governance of fisheries in the Southern Ocean, considering management, regulation and licensing. This is coupled with analysis of actors, networks, organisations and institutions, spanning local to international levels of decision-making, to explain a reduction in illegal fishing by $90 \%$ between 1997-2008 and how this fishery became more effectively regulated.

Despite governance being such a seemingly adroit term, there are quandaries and challenges in its deployment. Firstly, there are differences in the way core analytical terms are used such institutions, planning and policy. Secondly, there are multiple dimensions of governance, drawing on its use by multiple disciplines. The earth systems governance project strategy [81] outlines five dimensions, amongst which are: architecture, which relates to the structure of systems; agency, which relates to 
the roles undertaken by actors; and allocation, which considers what or who benefits. Thirdly, there are a variety of theoretical approaches with different underlying assumptions, as this paper outlines in section 2 . This variety has developed due to the diversity of approaches used in the social sciences to explore social reality.

Having reviewed concepts of planning, institutions and governance, the paper now turns to consider what opportunities theories and approaches to governance bring to understanding MSP as a form of spatial governance.

\section{Governance ApProaches for Marine Planning}

A range of contrasting approaches are used by different disciplines to analyse governance. Different theories seem to influence the kinds of solutions proffered by researchers- this is what is meant when research is termed 'theory-laden'. The variables and concepts which we choose to measure will affect how we evaluate MSP. Yet, theory itself can evolve based on the evidence gained from empirical research, to provide a better approximation to reality. Furthermore, reflexivity allows researchers to distinguish between theoretical approaches according to criteria such as their practical adequacy, explanatory power, productivity or efficacy for answering research questions ${ }^{7}$. Our aim is that the following review will support researchers and practitioners to understand or choose between approaches, by considering their logics of evaluation.

To support this task for studies of oceans governance and MSP, the following sections review 5 key approaches. These approaches may share certain concepts in common. They might be used in combination or combined to evaluate planning practice. We recognise that these approaches need not be mutually exclusive, but we argue that there is value in comparing their distinctiveness analytically. Each section introduces the history of ideas, critically examines key arguments and reviews how they shape evaluation of 'successful' marine planning. Some approaches such as 'Ecosystem-based management' are widely referenced in the marine planning and management literature, whilst others such as the 'good governance' principles have to date only been sparsely applied in empirical research on the oceans.

\subsection{ECOSYSTEM APPROACH, ECOSYSTEM-BASED MANAGEMENT}

Ecosystem-based management is currently the dominant paradigm for marine planning [82]. It is referenced in 15 out of 44 marine plans extant in 2017, and is also central to international guidelines on $\mathrm{MSP}^{8}$.

A constellation of terms with related meanings has evolved [83]. The Ecosystem Approach and Ecosystem Based-Management [EBM] can be considered broadly similar or interchangeable set of principles for managing the environment, with different terms enjoying dominance in different cultural groups. In some texts, these terms are viewed as highly complementary [84]- Ecosystem based management might be considered as a way of implementing an ecosystems approach. In other cases, the ecosystem approach is viewed as part of a continuum of concepts [85]. At one end of the

\footnotetext{
${ }^{7}$ Other criteria for theories: level of empirical support; verifiable/falsifiable, systematic and comprehensive.

${ }^{8}$ For example, UNESCO-IOC (2009) within the title and p18, 22, 24; The Nature Conservancy (2009), p.1; NOAA (2011); US National Ocean Council (2012) p.12; Convention on Biodiversity (2012), p.16; TPEA (2014) p.29, 32; ICES (2015) p13-16.
} 
spectrum, EBM might be considered an holistic approach to ecosystem assessment and management in contrast to conventional reductionistic or sectoral approaches to management [86]. At the other end of the spectrum it is argued that true ecosystem approach must promote ecological values and include cumulative impact assessment, the precautionary principle, resilience and ecosystem services as core components [87].

These sets of ideas developed from insights about the dynamic nature of natural systems within ecology [88] [89], and theories in environmental/resource management which critiqued the shortfalls of sectoral administration, based around administrative boundaries [90]. The wide acceptance of this set of principles stems from the fact that 12 principles for EA were codified by the Convention on Biodiversity $(2000)^{9}$ (See Table 1) The insights codified within the Ecosystem approach were developed through a series of international meetings (particularly Conventions of the Parties of the CBD between 1995 and 2004) drawing upon the experience of scientific and technical experts [91]. The EA was taken up by other international agreements which set the context for marine planning [92] at the international level by the UN and FAO, and supranational and national levels [e.g. UN General Assembly 2006, FAO ecosystem approach 2003, COMPASS statement in US and roadmap for MSP in EU]. It is significant that EA is codified as principle within EU law because of the way in which law guides implementation and regulation [93].

A considerable body of research has explored the interpretation of EBM principles in practice, and whether marine planning utilizes these principles. Rodriguez et al. [94] in a comparative study involving Norway, US, Australia, Canada and the EU finds that there is a wide variety of implementation of EBM, with emphasis of certain characteristics of EBM in certain traditions, such as the use of bioregional area definition and zoning in Canadian and US planning, and risk assessment and cumulative impact assessment in EU MSP. Douvere (2008) provides a positive assessment of the ability of Chinese and NW European MSP to implement EBM by attending to specific ecosystems and range of activities within an area [95]. Jones et al. [96] in their comparative study of 12 MSP initiatives in Europe find that an adaptive approach is largely absent in the implementation of MSP. They give a less positive evaluation of the state of governance overall, and contrast the ecosystem-based approach which prioritises good environmental status, against current approaches which have top down and short-term planning cycles. Hoel and Olsen [97] provide a generally positive assessment for Norwegian MSP (cf Table 1).

Considering the advantages of such an approach to evaluate marine planning, EA is currently the most widely accepted international set of principles. There is a remarkable political consensus around the term, if not grammatical agreement on the notion, which means that many MSP systems explicitly invoke this approach. The approach forms a comprehensive ethical compass for how marine planning should be done drawing on interdisciplinary understanding of both the natural and social sciencesencompassing principles such as participation and understanding of the structure and function of the dynamic ocean systems being governed. There is also clear alignment with other bodies of evidence related to marine space, for example with many common principles with integrated coastal and ocean management [98]. Although the approach was not specifically constructed with oceans in mind, research in the fields of marine and coastal biodiversity influenced the thinking behind EBM.

Considering critiques of such an approach to evaluate marine planning, although EBM is the closest to a comprehensive theory of oceans governance, as a theory it is an inconsistent set of propositions

\footnotetext{
${ }^{9}$ CBD 2000 Decision V/6 Ecosystem Approach.
} 
with very diverse referents. Perhaps this is one reason why it has proven challenging for marine planners to operationalise these concepts at the implementation phase. Indeed, the expressions of the Malawi principles, although grounded in extensive experience, read more like normative approach for governing the environment than a knowledge base developed through science and research, and would not qualify as a mid-range theory in the social sciences. Arguably EA is more commonly utilised as an approach for auditing or designing marine planning systems, whereas there is little empirical research has been done to explore whether the implementation of these ideas in the marine context leads, on balance, to the hoped for outcomes [99], notwithstanding the challenges of attributing success in sustainability. 
Table 1 Ecosystem based management/ Ecosystem Approach as a approach for MSP

\begin{tabular}{|c|c|c|c|}
\hline Step & $\begin{array}{l}\text { Malawi } \\
\text { Principle \# }\end{array}$ & Summary of Principle & $\begin{array}{l}\text { Application in MSP (Example: } \\
\text { Norway) }\end{array}$ \\
\hline \multirow[t]{2}{*}{$\begin{array}{l}\text { Step A1 Key } \\
\text { stakeholders }\end{array}$} & Principle 1 & $\begin{array}{l}\text { Objectives...a matter of } \\
\text { social choice }\end{array}$ & $\begin{array}{l}\text { Marine plan approved by National } \\
\text { Assembly }\end{array}$ \\
\hline & Principle 12 & $\begin{array}{l}\text { Involve all relevant } \\
\text { sectors of society and } \\
\text { scientific disciplines. }\end{array}$ & $\begin{array}{l}\text { No formal public input to white } \\
\text { papers but stakeholder inputs to } \\
\text { assessments. }\end{array}$ \\
\hline \multirow[t]{2}{*}{$\begin{array}{l}\text { Step A2 Area } \\
\text { analysis }\end{array}$} & Principle 7 & $\begin{array}{l}\text { At appropriate spatial } \\
\text { scale }\end{array}$ & $\begin{array}{l}\text { Delineation of management areas } \\
\text { from baseline based on regional seas }\end{array}$ \\
\hline & Principle 11 & $\begin{array}{l}\text { Consider all forms of } \\
\text { relevant information }\end{array}$ & $\begin{array}{l}\text { Interdisciplinary scientific and } \\
\text { sectoral assessments to support } \\
\text { pressure and impact report. }\end{array}$ \\
\hline \multirow[t]{4}{*}{$\begin{array}{l}\text { Step B Ecosystem } \\
\text { structure, } \\
\text { function and } \\
\text { management }\end{array}$} & Principle 5 & $\begin{array}{l}\text { Conservation of } \\
\text { ecosystem structure and } \\
\text { function to maintain } \\
\text { ecosystem services }\end{array}$ & $\begin{array}{l}\text { MPA network developed separately } \\
\text { from marine plan }\end{array}$ \\
\hline & Principle 6 & $\begin{array}{l}\text { Within the limits of } \\
\text { ecosystem functioning }\end{array}$ & $\begin{array}{l}\text { Specific measures to map seabed } \\
\text { ecosystems and safeguard } \\
\text { biodiversity }\end{array}$ \\
\hline & Principle 10 & $\begin{array}{l}\text { Appropriate balance and } \\
\text { integration of } \\
\text { conservation and use }\end{array}$ & $\begin{array}{l}\text { Unclear compromise between ocean } \\
\text { use and conservation }\end{array}$ \\
\hline & Principle 2 & $\begin{array}{l}\text { Decentralized to the } \\
\text { lowest appropriate level }\end{array}$ & $\begin{array}{l}\text { Cross-sectoral management fora for } \\
\text { regional seas }\end{array}$ \\
\hline $\begin{array}{l}\text { Step C Economic } \\
\text { Issues }\end{array}$ & Principle 4 & $\begin{array}{l}\text { Manage the ecosystem in } \\
\text { an economic context: } \\
\text { reduce market } \\
\text { distortions, align } \\
\text { incentives, internalise } \\
\text { costs and benefits. }\end{array}$ & $\begin{array}{l}\text { New cost-benefit analysis framework } \\
\text { for oil and gas sector. }\end{array}$ \\
\hline $\begin{array}{l}\text { Step D Adaptive } \\
\text { management } \\
\text { over space }\end{array}$ & Principle 3 & $\begin{array}{l}\text { Consider effects of } \\
\text { activities on adjacent and } \\
\text { other ecosystems }\end{array}$ & $\begin{array}{l}\text { Sequential development of sea } \\
\text { management plans 2006, 2009, } 2013\end{array}$ \\
\hline \multirow{3}{*}{$\begin{array}{l}\text { Step E Adaptive } \\
\text { Management } \\
\text { over time }\end{array}$} & Principles 7 & $\begin{array}{l}\text { At the appropriate } \\
\text { temporal scale }\end{array}$ & $\begin{array}{l}\text { Most of } 179 \text { measures in Barents Sea } \\
\text { plan implemented. }\end{array}$ \\
\hline & Principle 8 & $\begin{array}{l}\text { Recognizing varying } \\
\text { temporal scales and lag } \\
\text { effects...for the long term }\end{array}$ & $\begin{array}{l}\text { Plan review } 12 \text { years. Plan Measures } \\
\text { to address information gaps }\end{array}$ \\
\hline & Principle 9 & $\begin{array}{l}\text { Recognise that change is } \\
\text { inevitable }\end{array}$ & $\begin{array}{l}\text { Provision for plan updates every } 4 \\
\text { years. }\end{array}$ \\
\hline
\end{tabular}

Sources: After [100] Table 1.3, and Malawi Principles. Norway MSP: [94, 101, 102] 


\subsection{Good GovernanCE}

Good governance principles grew from the from development studies literature, based on reflections about the disjunct between aid and sustainable development and concerns relating to issues such as corruption. In response to the criticism of double standards, these criteria are now also being deployed at a global scale. There is also some commonality with legal principles of international ocean governance [103]. The core argument is a universal one- that successful governance is dependent upon good institutions. International institutions such as UNDP and World Bank, have been significant in defining sets of good governance principles [104]. These are formed of sets of ethical ideals including ideas around legitimacy, accountability, performance, and fairness (See Table 2). These themes may then be translated into principles and practices in marine planning or other contexts [105], for example the principle of transparency being reflected in freedom of information regulations or stakeholder communication tools of MSP.

Applications of this research approach specifically to MSP are rare in the literature. Some attempts at synthesis for environmental governance have been made [106]. In a broader maritime context, Turner et al. [107] consider governance of coral reef fisheries and MPAs, and show that where stakeholder perceptions of good governance are positive, this influences acceptance and engagement with management strategies. Soma et al. [108] review principles of accountability, legitimacy, responsibility, representation and transparency and posit that many of these are strongly related to the quality of participatory processes in marine governance. Objectives, timescales, skills and resources have also been found to effect the quality of participation [109] [110], with a proviso that participation itself does not prevent capture of the policy agenda by interest groups through small scale politics [111]. In a similar framing, Henocque and Kalaora [112] outline a range of facilitation, management, participation, adaptation and cross-cultural skills, and show how developing this kind of capacity in marine administrations would constitute a new form of governance which would help achieve integrated planning and poverty reduction goals.

Considering the advantages of such an approach to evaluate marine planning, good governance principles are relevant across legislative, administrative and operational domains, providing an evaluatory approach which goes beyond the planning process to the totality of the marine planning system. The resultant evaluation can be clearly linked to institutional reform. They have a relatively good fit with the principles of ecosystem-based management, on themes such as participation, decentralisation and accountability. The principles have been operationalised for a wide spread of programmes and institutions. Certain principles, such as the 'rule of law' have been operationalised within Ocean Governance Indicators (see below), but altogether empirical measurement has proven complex and has often relied on expert evaluation.

Considering critiques of such an approach to evaluate marine planning, in contrast to EBM there is a lack of an agreed, definitive list of principles. Since the major assumptions behind good governance are based on theories of democracy and ethical norms, it seems less likely that global agreement will be achieved soon. There also seems to be a lack of consideration how the principles relate to one another or sustainability. There is an emphasis on process-based principles such as participation, but less consideration of how these interact with outcome-based principles such as efficiency or performance. This suggests that good governance principles are quite removed from sustainability outcomes, rather at best they focus on pre-conditions for effective marine planning or emphasise the social dimension of sustainability. 
Table 2 Good Governance Principles as an approach for MSP

\begin{tabular}{|l|l|l|}
\hline $\begin{array}{l}\text { Good Governance } \\
\text { Principle (UNDP) }\end{array}$ & Sub-principles & Application in MSP \\
\hline Legitimacy & $\begin{array}{l}\text { Participation } \\
\text { Consensus orientation }\end{array}$ & $\begin{array}{l}\text { Dialogue, Trust, Shared and } \\
\text { owned rules }\end{array}$ \\
\hline Accountability & $\begin{array}{l}\text { Accountability } \\
\text { Transparency }\end{array}$ & $\begin{array}{l}\text { Stakeholder knowledge } \\
\text { Freedom of information }\end{array}$ \\
\hline Performance & $\begin{array}{l}\text { Responsiveness } \\
\text { Effectiveness and } \\
\text { Efficiency }\end{array}$ & $\begin{array}{l}\text { Competent administration } \\
\text { Institutional capacity }\end{array}$ \\
\hline Fairness & Equity & $\begin{array}{l}\text { Distribution of costs and } \\
\text { benefits } \\
\text { Conflict management }\end{array}$ \\
\hline Direction & Rule of Law & $\begin{array}{l}\text { Leadership } \\
\text { Collaborative Learning }\end{array}$ \\
\hline
\end{tabular}

Source: After [112] 


\subsection{GOVERNANCE INDICES AND STANDARDS}

Indicators have a long tradition of use within disciplines such as ecology and economics and for environmental regulation, but indicator sets for governance are a more recent development. From the 1990s International conferences on sustainable development made commitments to use both 'state' and 'performance' indicators [113]. At the same time, donor agencies and international organisations developed indicators of governance from programme evaluation, some of which were used to evaluate marine and coastal initiatives. Institutions such as the UNDP, World Bank and Freedom House developed these indicator sets in relation to the good governance criteria discussed above. The indicator sets have been taken-up in comparative political science to quantify governance 'performance' [114]. In this context, an indicator shows the presence or absence of a governance quality or condition. For governance purposes this is often expressed in a binary form or semiquantitatively allowing evaluators to distinguish between partial or full compliance (see Table 3). The indicator itself may also direct attention at a broader category- for example the absence of a particular policy or type of strategy might be taken to indicate a likely poor institutional capacity. Indicators can be aggregated together into an index, which utilises a formula to express an overall property (cf 'governance performance'). Where repeated measures are taken over time, this can be used to show improvement or variation from a given baseline. Other indicator sets focus less on establishing international trends and draw more on the tradition of auditing and environmental management systems to assist organisations or collectives to monitor their progress and diagnose opportunities for improved performance. The distinctiveness of this framing of governance lies in its auditing and ranking of key components of governance. At first impressions it might seem like this approach is less distinct from any of the other approaches considered here. Although an indicators approach might draw upon other approaches to define its variables, the key distinction is the way it measures variables semi-quantitatively, or by expressing presence/absence, and claims to provide an holistic evaluation of key elements (of MSP), including a rationale used for ranking or summarising results.

The Coastal Governance Index (cf Table 3 ) has been produced by Economist Intelligence Unit and launched at the world ocean summit, Portugal, $2015^{10}$. This followed an expert led approach to making the assessment and agreeing on the index construction, drawing upon history of indicatorbased approaches to marine and coastal governance [115]. It is a composite indicator set, with 43 sub-indicators in six categories used to construct overall rankings of national level governance performance. A second type of index draws upon ideas such as benchmarking in field of environmental standards. The ICES MSP quality management system [116] draws on ISO9000 standards and a range of marine quality objectives [117] to establish a series of procedures and activities for MSP within 8 major phases, from 'establishing the MSP external context' to 'monitoring \& review'. The Governance Baseline Tool [118] can be distinguished from other approaches to evaluation by its emphasis on 'adaptive learning' for a wide group of stakeholders involved in implementation. This goes beyond indicators to consider the dynamics of institutions and capacity building. It is also one of the governance approaches to explicitly consider second order 'sustainability' outcomes arising from the planning process. An application of this indicator set to the MSP in UK and Norway identifies the achievement of first order and some second order outcomes [119]; whilst evaluation at the regional scale for the state of Rhode Island, US [120] identified the significance of existing institutional capacity and investment in developing an evidence base as two key success

\footnotetext{
${ }^{10}$ https://events.economist.com/events-conferences/americas/world-ocean-summit/
} 
factors. Both ICES and Governance baseline indicators have explicit links to other governance approaches, especially EBM.

Table 3 Governance Indicators as an approach for MSP

\begin{tabular}{|c|c|c|}
\hline Governance Indicator & $\begin{array}{r}\text { US } \\
\text { Score } \\
2015 \\
(\%) \\
\end{array}$ & $\begin{array}{l}\text { Rank / } 28 \\
\text { countries }\end{array}$ \\
\hline 1) POLICY AND INSTITUTIONAL CAPACITY & 85 & 3 \\
\hline 1.1) Coastal management policy and strategy & 100 & $=1$ \\
\hline 1.2) Presence of established institution(s) & 100 & $=1$ \\
\hline 1.3) National strategy to adapt to climate change & 100 & $=1$ \\
\hline 1.4) Maritime Spatial Planning & 75 & 6 \\
\hline 1.5) Stakeholder engagement & 100 & $=1$ \\
\hline 1.6) Extractive industries transparency & 67 & $=8$ \\
\hline $\begin{array}{l}\text { 1.7) Adoption of the United Nations Convention on the Law of the Sea } \\
\text { (UNCLOS) }\end{array}$ & 50 & 19 \\
\hline 2) BUSINESS ENVIRONMENT FOR COASTAL ACTIVITIES & 86 & 4 \\
\hline 2.1) Ease of doing business & 80 & 2 \\
\hline 2.2) Corruption perception & 85 & 7 \\
\hline 2.3) Effectiveness of dispute resolution mechanisms & 100 & $=1$ \\
\hline 2.4) Quality of coastal infrastructure & 79 & 5 \\
\hline 3) WATER QUALITY & 80 & 5 \\
\hline 3.1) Agency & 100 & $=1$ \\
\hline 3.2) Regulatory standards for water pollution & 65 & 9 \\
\hline 3.3) Monitoring and enforcement & 75 & $=1$ \\
\hline 4) MINERALS AND ENERGY & 86 & $=3$ \\
\hline 4.1) Permitting and licensing & 100 & $=1$ \\
\hline 4.2) Monitoring and enforcement & 75 & $=1$ \\
\hline 4.3) Risk mitigation & 83 & $=4$ \\
\hline 5) LAND & 79 & 4 \\
\hline 5.1) Prevalence of coastal protected areas & 50 & $=7$ \\
\hline 5.2) Environmental impact of coastal development & 100 & $=1$ \\
\hline $\begin{array}{l}\text { 5.3) Government commitment to sustainability in coastal tourism } \\
\text { development }\end{array}$ & 67 & $=3$ \\
\hline 5.4) Natural disaster risk mitigation & 100 & $=1$ \\
\hline 6) LIVING RESOURCES & 97 & 1 \\
\hline 6.1) Fisheries governance and management effectiveness & 91 & 1 \\
\hline 6.2) Protection for marine/coastal species & 100 & $=1$ \\
\hline 6.3) Ballast water treatment & 100 & $=1$ \\
\hline
\end{tabular}

Source: [121] 
Whilst these indices remain somewhat a-theoretical, several studies draw on these or other indices to evaluate planning processes. Scott [122] explores the links between the Global Ocean Health Index ${ }^{11}$ and New Zealand MSP, arguing performance has been affected by failure to extend area-based management beyond the territorial sea and lack of adaptive management, but positively reinforced by public engagement and legal enshrinement of precautionary principle. Collie et al. [123] conduct an evaluation based on UNESCO MSP guidelines and 3 other MSP standards to review 16 case study MSP processes. They argued that outcome evaluations were not realistic at this early stage, but that there were real challenges in moving from tokenistic to genuine participation, and that legal, financial and human resources are key preconditions for successful marine planning. Day [124] cites the importance of combined status and performance indicators in making the case for re-zoning of the Great Barrier reef.

Considering the advantages of such an approach to evaluate marine planning, the development of an index allows quantification and thereby easier tracking of progress in governance. Quantification holds out the promise of being able to statistically analyse and identify patterns which are not apparent to human intuition. Where the metrics can be agreed and there is an appropriate outcome indicator this can support comparative analysis of MSP, especially where diagnostics enables tracking relationships with relevant output and outcome indicators in environmental, social and economic domains. Indices also provide a certain level of transparency, by making it simpler to track performance. In this sense they are a communication tools for transparency as well as an analytical device.

Considering critiques of such an approach to evaluate marine planning, whilst these indicator sets identify key components and their logical precedence, they do not establish the relative (theoretical) importance of factors, nor how the quality of implementation effects outcomes ${ }^{12}$. Indicators are usually developed through a parsimonious approach which seeks to capture broad goals by using representative indicators. This reduces complexity but does not always lead to deepening of understanding about the context, thus being better suited to comparison rather than supporting contextual evaluation, and at worst hides poorly supported causal assumptions. Where indices do evaluate performance, there is often a lack of a specific learning mechanism- with evaluations being divorced from those conducting MSP. Thus, on their own without complementary approach such as scenario planning, there is insufficient feedback to management and planning. More problematically, indices can become a political tool which uses perverse incentives or abstract performance standards to berate practitioners, whereas the actual causes behind the success or failure of MSP may be much broader or remain unknown.

\subsection{Modes of Governance (Collaborative, Networked, AdaPtive, TRANSFORMATIVE)}

The Modes of governance approach has arisen to explain the characteristics of governance and ways in which governing is being done. Government, private and third sector organisations can be given, or take on, different roles and competencies as actors within designed institutional arrangements

\footnotetext{
${ }^{11}$ http://www.oceanhealthindex.org/

12 Instead they rely on the assumption that conjunction between inputs and outputs shows a causal relation, or the assume that input variables are a proxy for outcomes.
} 
[125] [126]. Based on the combinations of these, as identified from research or as postulated in principle, ideal type theories have been posited such as collaborative governance or adaptive governance (See Table 4). These ideas can be traced to earlier theories in environmental management, natural resource management, environmental geography and conservation [127] [128] [129]) which explored the effectiveness of government programmes for managing the environment. Fields such as policy studies, marine affairs and political science have undertaken research about the effectiveness of types of regulatory tools, role of the state and broader issues of democracy, globalisation and government failure [130] [131]. As in the case of all other approaches, participatory approaches are key, inasmuch as the associated literature explores the relationship between state and non-state actors in marine planning [132].

Collaborative or networked governance, emphasises working in partnership across public, private and voluntary organisations, and building consensus around issues [133] [134]. The network concept emphasises groups and roles beyond the state, whereas the collaborative concept tends to denote partnership between state and other actors (Table 4). Market-based governance [135] can be considered another kind of mode, emphasising the efficiency of financial instruments or tools such as property rights with rents, to incentivise best practice or deter unsustainable behaviour (Table 4). Such an approach implicitly recognises that marine planning is seeking to influence economic activity and investment behaviour.

Adaptive governance highlights the learning element required for effective governance in contexts of uncertainty and the need for flexible institutional arrangements to adapt to shocks whilst maintaining identity [136] [137] (Table 4). Transformative governance stresses the role of norms and wider societal change in bringing about more sustainable approaches [138]. For example, issues related to sustainable fishing or renewable energy consumption might require changes in societal norms and private finance that equate to a cultural transformation. In many ways, the idea of a strategic (single) marine plan driving transformation is inimical to this mode, as it stresses that current policy failures are likely due to the incumbent regime [139]. But planning process could be designed more or less in ways which are multi-dimensional, multi actor, or multi-level to produce significant change (Table 4). For example, informal and decentralised and formal and centralised governance approaches could prove effective at different stages of a transformative processes [140].

In effect, most marine planning systems are hybrid forms of governance [141]. Jones [142] proposes a distinctive mode of 'co-evolutionary hierarchical governance' for marine planning, balancing the role of the state and other actors. This argument is based upon the unique interconnectedness of oceanic systems, and the ability of the state to provide strategic governance and regulatory steer in maritime jurisdictions. Scarff et al. [143] argue that UK MSP can still interpreted as an holistic but hierarchical, state-led approach, with an emphasis on regulatory efficiency and achieving development goals. Valman et al. [144] review the ability of the regime for the Baltic Sea to practice adaptive governance, and find that Baltic Sea plans provide a greater opportunity to adapt and revise goals across organisations, but the regime is still hampered by weak vertical integration. Tynkkynen maps the evolution of governance from hierarchical to networked forms in the Baltic and considers the challenges of uncertainty and complexity, and importance of dynamics of trust and identity [145]. In making such characterisations, the scholars commonly make assertions about the strengths and weakness of such modes. Other more theoretical papers critique assumptions behind these modes. [146] [147].

Considering the advantages of such an approach to evaluate marine planning, modes of governance can provide a theoretical grounding or ethos for particular formulations of marine planning. The modes present a way of summarising and testing the relationship between the design of governance and its outcomes, across diverse contexts. They encourage learning about the mix of tools and can 
also be used to interrogate elements of Good Governance or EBM, such as the collaborative ambition or adaptive learning within the MSP process.

Considering critiques of such an approach to evaluate marine planning, it has been argued that the modes of governance are not mutually exclusive, and that marine planning might implement aspects of many different modes in practice. There are also challenges about how such modes might be implemented in marine planning, and what scope there is for deliberate design of such systems. The level of abstraction draws attention away from the administrative and political capacities required to implement the modes, and allows the modes to remain somewhat idealistic. 
Table 4 Modes of Governance as an approach for MSP

\begin{tabular}{|c|c|c|c|}
\hline Mode & (Selected) Principles & $\begin{array}{l}\text { Example } \\
\text { Application in MSP }\end{array}$ & Example Outcomes for MSP \\
\hline \multirow[t]{4}{*}{$\begin{array}{l}\text { COLLABORATIVE/ } \\
\text { NETWORKED }\end{array}$} & $\begin{array}{l}\text { Government oversight and } \\
\text { service delivery }\end{array}$ & $\begin{array}{l}\text { High level marine } \\
\text { policy }\end{array}$ & $\begin{array}{l}\text { Policy coherence and } \\
\text { strategic direction }\end{array}$ \\
\hline & Multi-stakeholder partnerships & $\begin{array}{l}\text { Marine Planning } \\
\text { Partnerships }\end{array}$ & $\begin{array}{l}\text { Legal mandate, business } \\
\text { investment and civil society } \\
\text { innovation }\end{array}$ \\
\hline & $\begin{array}{l}\text { Co-operation of state/non-state } \\
\text { actors in implementation }\end{array}$ & $\begin{array}{l}\text { New networks for } \\
\text { policy delivery }\end{array}$ & $\begin{array}{l}\text { More effective } \\
\text { implementation of policy }\end{array}$ \\
\hline & $\begin{array}{l}\text { Dense forms of organisational } \\
\text { relationships }\end{array}$ & $\begin{array}{l}\text { Advocacy networks } \\
\text { to influence MSP }\end{array}$ & Stronger collective action \\
\hline \multirow[t]{4}{*}{ MARKET } & $\begin{array}{l}\text { Price incentives to change } \\
\text { behaviour }\end{array}$ & $\begin{array}{l}\text { - Subsidies } \\
\text { - Payment for } \\
\text { ecosystem } \\
\text { services } \\
\end{array}$ & $\begin{array}{l}\text { - Expanded sustainable } \\
\text { technologies } \\
\text { (renewables) } \\
\text { - New revenue streams } \\
\end{array}$ \\
\hline & $\begin{array}{l}\text { Formal rules to enforce } \\
\text { investment }\end{array}$ & $\begin{array}{l}\text { - Environmental } \\
\text { liability } \\
\text { - Environmental } \\
\text { controls- habitat } \\
\text { banking } \\
\end{array}$ & $\begin{array}{l}\text { - Management of hazards } \\
\text { and pollution risks. } \\
\text { - No net loss of habitats. }\end{array}$ \\
\hline & $\begin{array}{l}\text { Voluntary agreements and } \\
\text { informal cooperation }\end{array}$ & $\begin{array}{l}\text { - Partnership } \\
\text { financing }\end{array}$ & $\begin{array}{l}\text { - Public-private-voluntary } \\
\text { collaboration }\end{array}$ \\
\hline & $\begin{array}{l}\text { Reliable information to support } \\
\text { investor and consumer } \\
\text { behaviour }\end{array}$ & $\begin{array}{l}\text { Ecosystem } \\
\text { services } \\
\text { valuation } \\
\text { - Certification } \\
\text { schemes } \\
\end{array}$ & $\begin{array}{l}\text { - Information on } \\
\text { ecosystem service trade- } \\
\text { offs } \\
\text { - Certified sustainable } \\
\text { fisheries }\end{array}$ \\
\hline \multirow[t]{4}{*}{ ADAPTIVE } & $\begin{array}{l}\text { Polycentric, cross-scale } \\
\text { governance, integration and } \\
\text { power sharing }\end{array}$ & $\begin{array}{l}\text { Regional or local } \\
\text { marine planning } \\
\text { partnerships }\end{array}$ & Devolved decision-making \\
\hline & $\begin{array}{l}\text { Deliberation, Participation and } \\
\text { Collaboration. }\end{array}$ & $\begin{array}{l}\text { Data sharing in plan } \\
\text { making process }\end{array}$ & $\begin{array}{l}\text { Increased mutual } \\
\text { understanding }\end{array}$ \\
\hline & $\begin{array}{l}\text { Learning, Innovation and } \\
\text { Adaptability }\end{array}$ & $\begin{array}{l}\text { Formal plan review } \\
\text { process in iterative } \\
\text { plan cycle }\end{array}$ & $\begin{array}{l}\text { Greater reflexivity amongst } \\
\text { planning practitioners }\end{array}$ \\
\hline & $\begin{array}{l}\text { Self organisation and emergent } \\
\text { behaviour }\end{array}$ & Informal networks & $\begin{array}{l}\text { Shadow networks enable } \\
\text { collaboration }\end{array}$ \\
\hline \multirow[t]{4}{*}{ TRANSFORMATIVE } & $\begin{array}{l}\text { Enabling radical systemic shifts } \\
\text { in values, behaviour or regimes }\end{array}$ & $\begin{array}{l}\text { Novel problem } \\
\text { framing }\end{array}$ & $\begin{array}{l}\text { New narratives for ocean } \\
\text { sustainability }\end{array}$ \\
\hline & $\begin{array}{l}\text { Leadership, intermediaries and } \\
\text { capacity for experimentation }\end{array}$ & $\begin{array}{l}\text { Initiation of } \\
\text { transition } \\
\text { experiments }\end{array}$ & $\begin{array}{l}\text { Staged transitions to } \\
\text { decarbonise the economy } \\
\text { through marine renewables }\end{array}$ \\
\hline & $\begin{array}{l}\text { Interaction of formal } \\
\text { institutions and bottom up } \\
\text { change }\end{array}$ & $\begin{array}{l}\text { Investment in } \\
\text { participatory } \\
\text { planning process }\end{array}$ & $\begin{array}{l}\text { MSP as basis for legitimate } \\
\text { shift in status quo }\end{array}$ \\
\hline & $\begin{array}{l}\text { Encouraging innovation and } \\
\text { creative capacity }\end{array}$ & $\begin{array}{l}\text { Scenario planning } \\
\text { and visioning }\end{array}$ & $\begin{array}{l}\text { Envisioning alternative } \\
\text { futures }\end{array}$ \\
\hline
\end{tabular}

Sources: Collaborative-Networked [133, 148]; Adaptive [149]Transformative [138], and original 


\subsection{Multi-leVel GovernanCE}

Multi-level governance approaches have been inspired by thinking from contemporary social theory. Social theory is an umbrella term for traditions in social science which seek to understand how society operates, a broad set of ideas which form a paradigm for understanding the world. More specifically, MLG draws upon insights in political science and international relations. Scholarship in these fields commonly considers how states act to deal with common pool resource management issues, and how territorial governance is extended in the international sphere, of which the oceans, often divided between different jurisdictions, are a prime example. A recent trend in the governance of these common spaces is the proliferation of international regimes, such as those for the regional seas. As international regimes have developed, states and other kinds of actors have developed networks which act across scales. It can be argued that MLG governance approaches reflect a unique phase we have reached in the world history of globalisation.

A core insight of MLG is that politics and power play key a role in governing the oceans, which is otherwise neglected in other forms of analysis. In order to understand what happens and what will happen, there is a need to examine the internal logic of the governing system [150] [151] [152]. Such analyses draw on polycentric models to extend thinking about scales of governance, hence 'multilevel' [153] (Table 5). Often scale is conceived in terms of fixed territorial units, with power cascading hierarchically down from the international scale. In practice, it is possible that processes of regional marine planning might influence national or international planning, or that networks of actors have horizontal influence across multiple scales and sites. Consequently, the power that a spatial plan has to take effect and be implemented, cannot be separated from the mutual power relations between the organisations and actors that are its subject (in other words, it is assumed a plan does not have power of its own that extends in time and across space).

Questions of power lead to consideration of politics. Sometimes this is achieved in research through a political ecology framework which considers the inter-relationships between environmental and socio-political processes. Such a approach is able to theorise and evaluate marine planning, for example to highlight: the scalar politics and tensions between community scale management and broader spatial planning approaches [154]; whether planning processes embed stakeholders operating at different scales through cross-scale interlinkages [155]; the invisibility of certain stakeholders or sectors in the planning process, because of the nature of what counts as evidence in the planning process [156]; the challenge for planning systems to deal with trade-offs between marine conservation and development, especially where the institutional arrangements do not account for the politics of uneven access to resources [157] (cf Table 5). A key consideration of such analyses is which social groups stand to benefit or lose out in particular formulations of marine planning.

Another stream of research draws on political economy and political science to take a more technical approach to analyse decision-making through the lens of multi-level governance [158]. The EU has been a focus for this kind of analysis because of its role as a supranational institution spanning scales with a framework to promote MSP. Such analyses consider mutual adjustments between different scales within marine planning system, for example: ways in which regionalisation has enabled better cooperation and integration for MSP [159]; opportunities for institution building and greater reflexivity across different jurisdictions [160]; competing interpretations as to what scale MSP should be conducted within sea area [161]; or how geopolitical factors (such as desire to extend control further offshore, or competition between different levels of administration) impinge on the design of planning systems [162] (cf Table 5).

Questions of power also lead to consideration of values, and the role dominant value sets which shape the governance system. Ritchie provides an analysis of how the design of the UK marine planning system was influenced by a new labour government rhetoric of state intervention for regional 
sustainability and smarter regulation [163]. A rapidly growing body of literature has explored the logic of 'blue growth' and the centrality of this discourse to marine planning regimes [164] [165]. Questions of power also lead to consideration of agency, inasmuch as innovation in marine planning maybe achieved through individual leadership or through the active formation of informal networks [166]. Whilst not all of these approaches invoke multi-level governance nor particular social theories, the notion of multiple actors at different scales is implicit in the consideration of why certain configurations of planning to come exist, and how planning works out.

Considering the advantages of such an approach to evaluate marine planning, MLG takes account of the reality of 'big $P$ ' politics (the contested processes of formal government and administration) and 'small $P^{\prime}$ politics (micropolitics of everyday decision-making), and how interest groups and coalitions seek to steer the marine planning process. In contrast to some other approaches, which focus on linear processes and rational behaviour, MLG reveals the iterative nature of the policy process, and has high explanatory power, especially in western contexts which are characterised by MLG. The framing of MLG is also relevant for increasing transnational contexts, where organisations are seeking to implement cross-border planning.

Considering critiques of such an approach to evaluate marine planning, MLG seems to be productive in explaining why marine planning is taking various forms, but it seems to offer less practical or substantive guidance on how to implement marine planning. It could be argued that the social justice problems identified by these analyses do have some implications for design principles, but MLG assumptions about the politicisation of planning mean that this is rarely considered as a practical matter. The level of abstraction taken by MLG can be considered both an advantage and disadvantage, since it is concerned with general patterns of institutional arrangements it can explore the design of the planning system as a whole, but it provides little guidance for the detailed process plan-making compared with the approach of governance indicators and standards, or systematic planning which suggests practical steps.

Table 5 Multi-level Governance approach for MSP

\begin{tabular}{|c|c|c|c|}
\hline Level & Example Actors & Example Processes & MLG Analytic \\
\hline Global & United Nations & \multirow{7}{*}{$\begin{array}{l}\text { Creation of political } \\
\text { structures } \\
\text { Political mobilisation } \\
\text { Policy making } \\
\text { processes } \\
\text { Processes which } \\
\text { shape capacity, } \\
\text { political struggles and } \\
\text { political will }\end{array}$} & \multirow{7}{*}{$\begin{array}{l}\text { - Interactions } \\
\text { between scales } \\
\text { - Power relations } \\
\text { between actors } \\
\text { - Agency of key } \\
\text { actors } \\
\text { - Key discourses } \\
\text { - Politics of access to } \\
\text { resources and } \\
\text { influence on } \\
\text { decisions } \\
\text { - (Geo)political } \\
\text { influences/values }\end{array}$} \\
\hline $\begin{array}{l}\text { International } \\
\text { (Multilateral) }\end{array}$ & $\begin{array}{l}\text { International Council } \\
\text { on the Exploration of } \\
\text { the Seas }\end{array}$ & & \\
\hline Supranational & European Union & & \\
\hline Regional & $\begin{array}{l}\text { OSPAR Convention for } \\
\text { North East Atlantic }\end{array}$ & & \\
\hline National & State government & & \\
\hline Sub-national Regional & $\begin{array}{l}\text { Regional Planning } \\
\text { Body }\end{array}$ & & \\
\hline Local/municipal & Local government & & \\
\hline
\end{tabular}

Source: original. 


\subsection{OTHER APPROACHES-}

The above traditions of research are evolving, and new approaches are emerging. A parallel debate has been conducted on frameworks for evaluating Integrated Coastal Management [115, 167-172].

Other governance approaches may be relevant to the evaluation of marine planning which are not included in the categorisation above. In this final section of the body of the paper, we briefly consider a range of approaches emerging in the marine planning literature. Policy implementation frameworks trace the ways in which plan policies have been taken forward, and analyse the importance of factors such as political leadership in the different phases of design and implementation [101, 102]. Implementation may be considered as distinct from design of institutions, and sometimes failures in implementation arise from the lack of sensitivity in applying frameworks to a given context. Notions of institutional fit and interplay [68] [173] frame assessment on the level of match between ecosystem dynamics and planning regimes, as well as fit in interactions between institutional players. A poststructuralist approach allows deconstruction of political claims and how they have come to be dominant in marine planning [174]. This has been described this as a change in analytical perspective from governance to governmentality. A 'Relational' approach planning seeks to enable consideration of how space is socially constructed and open to the complex interactions of human and non-human actors within the unique marine environment [175]. A 'performative' approach engages with how planning narratives and political inscription assemble people, places and technologies for the oceans, and whether these 'restrict' or 'expand' the capacities of actors [176]. Radical planning is been put forward as an approach to consider power relations. Some argue that this idea can move MSP from a technocratic approach which serves elites towards consideration of distributional justice or social outcomes [177]. Others question assumptions of how marine planning has been framed, considering notions of 'participation', 'integration' and 'balancing' as fundamentally obscuring the political nature of planning as a site for conflict and contest [178]. In many post-structuralist framings it is unclear how discourses can be judged as better or worse, rather we are left with the analysis that some are 'dominant' and certain groups stand to lose from this. 


\section{Comparative Analysis}

In this section we seek to summarise some of the distinctive aspects of each approach and compare their strengths and weaknesses.

Although the five approaches have been presented as distinct, elements can and do overlap in 'real world' practice. Practical guidelines on MSP such as the ICES MSP quality management system [116] and UNESCO Guidelines for evaluating MSP [179] draw on more than one of these approaches. Other combinations might be imagined. Good governance for example could be viewed from a perspective of multi-level governance, or modes of governance might employ governance indicators. The point of this analysis, however, is to review each approach as an analytical lens, or way of looking at MSP as a specific form of spatial governance. Each approach seems to have distinctive focus: EBM focuses on the principles of governance, Good governance on character of institutions, Governance Indices on core components of governance, Modes on the characteristics of governance, Multi-level Governance on interactions between entities of governance. Other approaches focus on the plan making process, controlling discourses, power dynamics, fit and interplay.

For the Ecosystem approach, evidence from the literature arguably shows an emerging consensus on this approach. This is confirmed by MSP practice, where there is broad reference to the ecosystem approach in existing and emerging plans or national and international MSP frameworks. As a approach, EBM can be said to focus on principles of governance. The principles are well grounded in over two decades of experience and practice. But these principles have been generated inductively, rather than tested abductively in the oceans. There are many examples of studies which test whether programmes have implemented EBM, but too few studies which evaluate whether the implementation of EBM principles led, on balance, to the achievement of sustainability outcomes. Conceptually, this approach is therefore some way from being a theory with propositions. Ecosystem based management seems to offer the broadest rationale for the design of components of a marine planning system, because its principles are predicated on the social character of governance and the character of (marine) environmental space- therefore to design marine planning with these principles is to design it to fit with its context. The EA paradigm is also most clearly focused on sustainability outcomes, compared for instance with Modes of governance which offer a choice between for example, hierarchical, adaptative or other modes governance, and the possibility of considering the advantages and disadvantages associated with each. Taking the 12 Malawi Principles as a proxy of the ecosystem approach, and the number of it's principles which refer to ecosystem functioning, there is a strong emphasis on sustainability. In contrast, the single principle on 'objectives being a matter of social choice' offers little guidance on how institutions might be designed, compared to the complexity of theories like the adaptive mode of governance.

The good governance paradigm is more concerned with the character of institutions and provides core ethical arguments for the design of processes and institutions within marine planning. However, there is less agreement about the nature of these principles and it is challenging to overcome the argument that these are simply 'normative' positions based upon beliefs about how a democratic society should function, rather than 'instrumental' values which justify substantive outcomes for sustainability. Nevertheless, they potentially constitute important metagovernance principles for MSP and could strengthen elements that contribute to social sustainability in MSP, such as enhancing transparency or equal participation.

Governance indicators and standards encourage quantification and systematization of various components of governance. These may prove beneficial for MSP in terms of performance evaluation, 
explicit tracking of inputs with outputs and outcomes; but quantifying governance comes with a number of challenges: simplification; problematic assumptions related to cause-effect relationships; and data-driven measurement (of individual indicators and index weighting and scoring). Nevertheless, an emphasis on indicators can provide a helpful focus on end goals and outcomes which are somewhat lacking in other approaches. Furthermore, where coupled with a reflective learning element, this can embed evaluation within the marine planning system, emphasising the cyclical and adaptive nature of marine planning.

In considering the characteristics of governance, modes of governance open up a debate about the relative success of different designs for marine planning and the relative roles of government, markets, civil society and social movements. Some modes are better represented in Marine Planning than others, and it remains to be seen whether this is because of a particular phase in the history of the development of marine planning or whether the nature of ocean space influences what is possible. Existing legal frameworks (such as rules for participation) and planning traditions may predispose a country or region towards a particular mode of governance in MSP; there is also institutional path dependency which may restrict the ability to choose between modes of governance once a course has been set. Nevertheless, modes get to the central point about effectiveness of different kinds of institutional arrangements for marine planning, and go some way beyond technocentric approaches to MSP, most frequently presented as a rational synoptic model in technical marine planning guidance.

Multi-level governance theory brings politics, values and power into the analysis. In considering the various interactions between entities of governance, it shifts the focus from planning and regulation, to the contested nature of plan making across scales and the resources and activities being governed. This seems to best describe how marine planning works in the real world, especially in Europe where regional seas have become an important arena for negotiating a multi-level approach to plan-making.

None of the above approaches truly originate within MSP, and all clearly point beyond Marine Planning. Viewing MSP from a governance perspective, reveals that it is one amongst many tools relevant to the governance of the marine environment. One critique could be that a governance framing obscures or neglects practical planning, management and regulation. Yet practical implementation will be a relevant consideration whichever governance approach is chosen for MSP. As mentioned earlier, there is a continued need for research which assesses the operational aspects of planning. A number of techniques have been designed to evaluate the plan making process [180] [179] and its impacts [181]. But questions about whether a Marine Spatial Planning process will, for example, encourage sustainable small-scale fishing, will need to attend to institutional arrangements, procedural values and political framings inherent in the planning system, which can be expounded using a governance perspective. Indeed, these issues are often fundamental points of contention and debate.

\section{ConClusions}

It is often claimed that marine spatial planning is a key tool for the sustainability of the oceans ${ }^{13}$. Yet critiques of planning argue that planning is a process seeking a substantive basis. One way to

\footnotetext{
${ }^{13}$ Maritime Spatial Directive 2014/89/EU preamble 14, 22, article 25; Helcom (2016) Guideline for the implementation of ecosystem-based approach in MSP in the Baltic Sea area; UNEP/MAP (2013) Roadmap for
} 
circumvent this challenge is to theorise planning as a form of governance, where governance constrains or enables certain types of plan making and planning outcomes [70]. Yet this strategy presents a new conundrum- how should researchers distinguish between the multiple approaches which purport to provide a theory of governance?

One way of comparing the above approaches is to see them as essentially complementary. In this reading, each governance approach reveals a different kind of evidence about marine planning. For example, the good governance approach focuses on the quality of institutions- any findings would have implications for meta-governance principles for MSP, the checks and balances on how decisions are made. The answer to the question of which theoretical approach offers the most traction, in this case, would then depend on which question is being asked about MSP. The choice of approach can depend on a researcher's interest in a particular aspect of MSP.

Another way of understanding the above approaches is to see them as essentially antagonistic. This reading is supported by an understanding of the research philosophies which underlie each of the approaches, and the logical contradictions which they entail. For example, EBM, Modes of Governance, Policy implementation frameworks, and Governance Indices rely on cross-contextual lesson drawing, comparative analysis, or other forms of empirical theory building. In contrast, Good Governance, Multi-level Governance, and Relational Governance investigate realm of values through more pluralistic or interpretive approaches, including political ecology, assemblage thinking or genealogical deconstruction.

At the root of this antagonism, are questions about sound scholarship and the philosophy of social scientific research. Making a very broad categorisation, approaches which attend to politics and power arguably reveal more of why marine planning fails to achieve sustainability outcomes, or how marine planning regimes become structured (for example, the blue growth agenda). One might argue that in doing so such studies make social consensus the yardstick of what is right, and substitute coercion about 'norms', instead of knowledge arising out of experience, as the arbiter of what should happen in marine planning. Approaches which emphasise more traditional social scientific methods seek to understand the regularities of how marine planning works out, and build modest (or grand) theories to inform planning, consisting of a series of 'if-then' premises. One might argue that such approaches depend on a highly instrumental notion of rationality, risk being silent about autocratic approaches, and tend to overstate regularities, at the expense of understanding context.

At the present stage in the history of social sciences and sustainability science, final arbitration between these approaches seems far off. However, it does not follow that all approaches are equally valid or productive. This entails that researchers justify their first assumptions. The answer to which governance approach offers the most traction for evaluating MSP, in this case, would depend upon some broader philosophical positions about knowledge creation which a researcher finds most justified.

Yet another way of reading the above five approaches is to see them as potentially dialogic. In this reading the governance approaches might learn from one another's findings, and have the potential to move towards some kind of synthesis, or maybe simply refine or even refute a given approach. The answer to which governance approach offers the most traction for evaluating MSP, in this case, should

implementing ecosystem based approach; US National Ocean Council (2013) Marine Planning Handbook. p.1213; Secretariat of the Convention on Biodiversity (2012) Marine Spatial Planning in the context of the Convention on Biodiversity. p.16 
be judged by the performance of these approaches to give a deeper understanding of what MSP achieves and how it does this. In our analysis we have offered a critique of the strengths and weaknesses of each approach. However, we have refrained from recommending a single approach or synthesis, as we believe there is a need for greater mutual dialogue and debate across the literature, and there is potential for a new synthesis to emerge. We observed that Ecosystem based management is the dominant framework in current practice. By comparing the productivity of governance approaches [182] [183] [184], theory can be mobilised to inform practicable marine planning. Doing such comparison provokes questions amongst researchers which should help relate their studies to practice: Is this framework applicable to the domain of the oceans? Why are proponents are arguing for a certain approach to marine planning? Can we provide evidence about what arrangements tend to lead to sustainability? How can we make progress in the challenge of understanding what constitutes 'success' or 'good' governance?

\section{REFERENCES}

1. Smith, H.D., J.L.S. de Vivero, and T.S. Agardy, eds. Routledge Handbook of Ocean Resources and Management. 2016, Routledge.

2. Cicin-Sain, B., D. VanderZwaag, and M.C. Balgos, eds. Routledge Handbook of National and Regional Ocean Policies. 2015, Routledge: Abingdon, Oxford.

3. Couper, A.D., ed. Times Atlas and Encyclopaedia of the Sea. 1989, HarperCollins.

4. Zacharias, M., Marine Policy: An Introduction to Governance and International Law of the Oceans. 2014: Routledge.

5. United Nations, Summary: First Global Integrated Marine Assessment (First World Ocean Assessment). 2015, Division for Ocean Affairs and the Law of the Sea, Office of Legal Affairs, United Nations: New York.

6. Ostrom, E., Background on the Institutional Analysis and Development Framework. Policy Studies Journal, 2011. 39(1): p. 7-27.

7. Frazão Santos, C., et al., Chapter 30 - Marine Spatial Planning, in World Seas: an Environmental Evaluation (Second Edition), C. Sheppard, Editor. 2019, Academic Press. p. 571-592. http://dx.doi.org/https://doi.org/10.1016/B978-0-12-805052-1.00033-4

8. Varjopuro, R., Evaluation of Marine Spatial Planning: Valuing the Process, Knowing the Impacts, in Maritime Spatial Planning: past, present, future, J. Zaucha and K. Gee, Editors. 2019, Palgrave Mcmillan. https://doi.org/10.1007/978-3-319-98696-8 18

9. Taylor, Z., Rethinking planning culture: A new institutionalist approach. Town Planning Review, 2013. 84(6): p. 683-702. http://dx.doi.org/10.3828/tpr.2013.36

10. Allmendinger, P., Towards a post-positivist typology of planning theory. Planning Theory, 2002. 1(1): p. 77-99. http://dx.doi.org/10.1177/147309520200100105

11. Lindblom, C.E., Still muddling, not yet through. Public Administration Review. Nov-Dec 1979, 1979. 39(6): p. 517-26.

12. Flyvbjerg, B., Phronetic planning research: theoretical and methodological reflections. Planning Theory \& Practice, 2004. 5(3): p. 283-306. http://dx.doi.org/10.1080/1464935042000250195

13. Gazzola, P., M.H. Roe, and P.J. Cowie, Marine spatial planning and terrestrial spatial planning: reflecting on new agendas. Environment and Planning C: Government and Policy, 2015. 33(5): p. 1156-1172. http://dx.doi.org/10.1177/0263774x15612317

14. Selman, P., Social capital, sustainability and environmental planning. Planning Theory and Practice, 2001. 2(1): p. 13-30. http://dx.doi.org/10.1080/14649350122850

15. Healey, P., Planning through debate: the communicative turn in planning theory. Town Planning Review, 1992. 63(2): p. 143-162. 
16. Healey, P., Collaborative Planning in perspective. Planning Theory, 2003. 2(2): p. 101-123. http://dx.doi.org/10.1177/14730952030022002

17. De Roo, G. and G. Porter, Actor consulting. DISP, 2015. 51(2): p. 16-27. http://dx.doi.org/10.1080/02513625.2015.1064644

18. Shaw, D. and A. Lord, From land-use to 'spatial planning': Reflections on the reform of the English planning system. Town Planning Review, 2009. 80(4): p. 415. http://dx.doi.org/10.3828/tpr.2009.5

19. Wong, C. and C. Watkins, Conceptualising spatial planning outcomes: Towards an integrative measurement framework. Town Planning Review, 2009. 80(4): p. 481. http://dx.doi.org/10.3828/tpr.2009.8

20. Ehler, C., J. Zaucha, and K. Gee, Maritime/Marine Spatial Planning at the interface of research and practice, in Maritime Spatial Planning: past, present, future, J. Zaucha and K. Gee, Editors. 2019, Palgrave Mcmillan. http://dx.doi.org/10.1007/978-3-319-98696-8

21. Shaw, D. and O. Sykes, The concept of polycentricity in European spatial planning: Reflections on its interpretation and application in the practice of spatial planning. International Planning Studies, 2004. 9(4): p. 283-306. http://dx.doi.org/10.1080/13563470500050437

22. Boyes, S.J., et al., A proposed multiple-use zoning scheme for the Irish Sea. An interpretation of current legislation through the use of GIS-based zoning approaches and effectiveness for the protection of nature conservation interests. Marine Policy, 2007. 31(3): p. 287-298. http://dx.doi.org/10.1016/i.marpol.2006.08.005

23. Fang, Q., et al., How effective is a marine spatial plan: An evaluation case study in China. $\begin{array}{lllll}\text { Ecological } & \text { Indicators, } & 2019 . & \text { 98: } & \text { p. }\end{array}$ http://dx.doi.org/https://doi.org/10.1016/i.ecolind.2018.11.028

24. Agardy, T., G.N. di Sciara, and P. Christie, Mind the gap Addressing the shortcomings of marine protected areas through large scale marine spatial planning. Marine Policy, 2011. 35(2): p. 226-232. http://dx.doi.org/10.1016/j.marpol.2010.10.006

25. Sanchirico, J.N., et al., Comprehensive planning, dominant-use zones, and user rights: A new era in ocean governance. Bulletin of Marine Science, 2010. 86(2): p. 273-285.

26. Maes, F., The international legal framework for marine spatial planning. Marine Policy, 2008. 32(5): p. 797-810. http://dx.doi.org/10.1016/j.marpol.2008.03.013

27. Fang, Q., et al., Marine Functional Zoning in China: Experience and Prospects. Coastal Management, 2011. 39(6): p. 656-667. http://dx.doi.org/10.1080/08920753.2011.616678

28. Lédée, E.J.I., et al., Responses and adaptation strategies of commercial and charter fishers to zoning changes in the Great Barrier Reef Marine Park. Marine Policy, 2012. 36(1): p. 226-234. http://dx.doi.org/10.1016/j.marpol.2011.05.009

29. Smith, H.D., et al., The integration of land and marine spatial planning. Journal of Coastal Conservation: Planning and Management, 2011. 15(2): p. 291-303 http://dx.doi.org/10.1007/s11852-010-0098-z

30. Jay, S., From disunited sectors to disjointed segments? Questioning the functional zoning of the sea. Planning Theory and Practice, 2013. 14(4): p. 509-525. http://dx.doi.org/10.1080/14649357.2013.848291

31. Wright, G., Marine governance in an industrialised ocean: $A$ case study of the emerging marine renewable energy industry. Marine Policy, $2015 . \quad 52$ : p. 77-84. http://dx.doi.org/10.1016/j.marpol.2014.10.021

32. Bocci, M., et al., Multi-use of the sea: $A$ wide array of opportunities from site-specific cases across Europe. PLoS ONE, 2019. 14(4). http://dx.doi.org/10.1371/journal.pone.0215010

33. Lighthill, J., Multiple sea use. Interdisciplinary Science Reviews, 1977. 2(1): p. 27-35. http://dx.doi.org/10.1179/isr.1977.2.1.27

34. Smith, H.D., Management and Administration of the Sea. Area, 1985. 17 (2): p. 109-115. 
35. Miles, E.L., Concepts, approaches, and applications in sea use planning and management. Ocean Development and International Law, 1989. 20(3): p. 213-238. http://dx.doi.org/10.1080/00908328909545891

36. Vallejo, S.M., Development and Management of Coastal and Marine Areas: An International Perspective. Oceans Yearbook, 1988. 7: p. 205-222.

37. DiMento, J.F. and A.J. Hickman, Environmental governance of the great seas: law and effect. New Horizons in Energy and Environmetal Law. 2012, Cheltenham, UK: Edward Elgar. http://dx.doi.org/10.4337/9781781006153

38. Billé, R. and J. Rochette, Bridging the gap between legal and institutional developments within regional seas frameworks. International Journal of Marine and Coastal Law, 2013. 28(3): p. 433-463. http://dx.doi.org/10.1163/15718085-12341277

39. Kenchington, R.A. and J.C. Day, Zoning, a fundamental cornerstone of effective Marine Spatial Planning: Lessons learnt from the Great Barrier Reef, Australia. Journal of Coastal Conservation, 2011. 15(2): p. 271-278. http://dx.doi.org/10.1007/s11852-011-0147-2

40. Douvere, F. and C.N. Ehler, New perspectives on sea use management: Initial findings from European experience with marine spatial planning. Journal of Environmental Management, 2009. 90(1): p. 77-88.

41. Kidd, S. and G. Ellis, From the Land to Sea and Back Again? Using Terrestrial Planning to Understand the Process of Marine Spatial Planning. Journal of Environmental Policy \& Planning, 2012. 14(1): p. 49-66. http://dx.doi.org/10.1080/1523908x.2012.662382

42. Kidd, S. and D. Shaw, The social and political realities of marine spatial planning: Some landbased reflections. ICES Journal of Marine Science, 2014. 71(7): p. 1535-1541. http://dx.doi.org/10.1093/icesjms/fsu006

43. Ehler, C. and F. Douvere, Step-by-Step Approach for Marine Spatial Planning toward Ecosystem-based Management. 2009, UNESCO: Paris.

44. Jay, S., Built at sea: Marine management and the construction of marine spatial planning. The Town Planning Review, 2010. 81(2): p. 173-191. http://www.jstor.org/stable/40660676

45. University Gent and Federal Science Policy, A flood of space. Towards a spatial structure plan for sustainable management of the North Sea (GAUFRE) 2005.

46. Hull, A.D., Managing Competition for Marine Space Using the Tools of Planning in the UK. Planning Practice and Research, 2013. 28(5): p. 503-526. http://dx.doi.org/10.1080/02697459.2013.812375

47. Retzlaff, R. and C. LeBleu, Marine Spatial Planning: Exploring the Role of Planning Practice and Research. Journal of Planning Literature, 2018: p. 0885412218783462. http://dx.doi.org/10.1177/0885412218783462

48. Flannery, W., et al., Exploring the winners and losers of marine environmental governance/Marine spatial planning: Cui bono?/"More than fishy business": epistemology, integration and conflict in marine spatial planning/Marine spatial planning: power and scaping/Surely not all planning is evil?/Marine spatial planning: a Canadian perspective/Maritime spatial planning - "ad utilitatem omnium"/Marine spatial planning: "it is better to be on the train than being hit by it"/Reflections from the perspective of recreational anglers and boats for hire/Maritime spatial planning and marine renewable energy. Planning Theory \& Practice, $2016.217(1): \quad$ p. $121-151$. http://dx.doi.org/10.1080/14649357.2015.1131482

49. Gazzola, P. and V. Onyango, Shared values for the marine environment - developing a culture of practice for marine spatial planning. Journal of Environmental Policy \& Planning, 2018: p. 1-14. http://dx.doi.org/10.1080/1523908X.2018.1438253

50. Steinberg, P. and K. Peters, Wet Ontologies, Fluid Spaces: Giving Depth to Volume through Oceanic Thinking. Environment and Planning D: Society and Space, 2015. 33: p. 247-264., https://doi.org/10.1068/d14148p 
51. Davoudi, S. and J. Pendlebury, Centenary paper: The evolution of planning as an academic discipline. Town Planning Review, 2010. 81(6): p. 613-645. http://dx.doi.org/10.3828/tpr.2010.24

52. Mazza, L. and M. Bianconi, Which aims and knowledge for spatial planning? Some notes on the current state of the discipline. Town Planning Review, 2014. 85(4): p. 513-531. http://dx.doi.org/10.3828/tpr.2014.29

53. Alexander, E., R., There is no planning-only planning practices: Notes for spatial planning theories. Planning $2015 . \quad$ 15(1): p. 91-103. http://dx.doi.org/10.1177/1473095215594617

54. King, T.J. and G. Robinson, eds. At Home on the Waves. Human Habitation of the Sea from the Mesolithic to Today. 2019, Berghahn: New York.

55. Elliott, M., S.J. Boyes, and D. Burdon, Integrated marine management and administration for an island state-the case for a new Marine Agency for the UK. Marine Pollution Bulletin, 2006. 52(5): p. 469-474.

56. Juda, L., Changing national approaches to ocean governance: The United States, Canada, and Australia. Ocean Development and International Law, 2003. 34(2): p. 161-187. http://dx.doi.org/10.1080/00908320390209627

57. Carneiro, G., The parallel evolution of ocean and coastal management policies in Portugal. Marine Policy, 2007. 31(4): p. 421-433. http://dx.doi.org/10.1016/j.marpol.2007.02.002

58. Chang, Y.C. and N. Wang, The Restructuring of the State Oceanic Administration in China: Moving Toward a More Integrated Governance Approach. International Journal of Marine and Coastal Law, 2015. 30(4): p. 795-807. http://dx.doi.org/10.1163/15718085-12341371

59. Koivurova, T., A Note on the European Union's Integrated Maritime Policy. Ocean Development \& International Law, 2009. 40(2): p. 171 - 183. http://www.informaworld.com/10.1080/00908320902864904

60. Lubchenco, J. and N. Sutley, Proposed U.S. policy for ocean, coast, and great lakes stewardship. Science, 2010. 328(5985): p. 1485-1486. http://dx.doi.org/10.1126/science.1190041

61. Potts, T., T. O'Higgins, and E. Hastings, Oceans of opportunity or rough seas? What does the future hold for developments in European Marine policy? Philosophical Transactions of the Royal Society A: Mathematical, Physical and Engineering Sciences, 2012. 370(1980): p. 56825700. http://dx.doi.org/10.1098/rsta.2012.0394

62. Suárez-de Vivero, J.L. and J.C. Rodríguez Mateos, Changing maritime scenarios. The geopolitical dimension of the EU Atlantic Strategy. Marine Policy, 2014. 48: p. 59-72. http://dx.doi.org/https://doi.org/10.1016/i.marpol.2014.03.016

63. Kidd, S., Rising to the integration ambitions of Marine Spatial Planning: Reflections from the Irish Sea. Marine Policy, 2013. 39(0): p. 273-282. http://dx.doi.org/http://dx.doi.org/10.1016/j.marpol.2012.11.004

64. Smythe, T.C. and J. McCann, Achieving integration in marine governance through marine spatial planning: Findings from practice in the United States. Ocean and Coastal Management, 2019. 167: p. 197-207. http://dx.doi.org/10.1016/j.ocecoaman.2018.10.006

65. Imperial, M.T., Institutional analysis and ecosystem-based management: The institutional analysis and development framework. Environmental Management, 1999. 24(4): p. 449-465. http://dx.doi.org/10.1007/s002679900246

66. Voss, T.R., Institutions, in International Encyclopedia of the Social \& Behavioral Sciences, N.J. Smelser and P.B. Baltes, Editors. 2001, Pergamon: Oxford. p. 7561-7566.

67. Young, O.R., L.A. King, and H. Schroeder, eds. Institutions and environmental change. 2008, MIT Press: Cambridge.

68. Young, O.R., Effectiveness of international environmental regimes: Existing knowledge, cutting-edge themes, and research strategies. Proceedings of the National Academy of Sciences of the United States of America, 2011. 108(50): p. 19853-19860. http://dx.doi.org/10.1073/pnas.1111690108 
69. Frantzi, S., N.T. Carter, and J.C. Lovett, Exploring discourses on international environmental regime effectiveness with $Q$ methodology: A case study of the Mediterranean Action Plan. Journal of Environmental Management, 2007. http://dx.doi.org/10.1016/i.jenvman.2007.08.013

70. Schmitt, P. and T. Wiechmann, Unpacking Spatial Planning as the Governance of Place: Extracting Potentials for Future Advancements in Planning Research. DISP, 2018. 54(4): p. 2133. http://dx.doi.org/10.1080/02513625.2018.1562795

71. Vallega, A., Sea Management. A Theoretical Approach. 1992, London: Elsevier.

72. Bevir, M., Governance. A very short introduction. 2012, Oxford: Oxford University Press.

73. Evans, J.P., Environmental Governance. 2012, London: Routledge.

74. Bevir, M., Key Concepts in Governance. 2009, Los Angeles: Sage.

75. Haward, M. and J. Vince, Oceans Governance in the Twenty-first Century. Managing the Blue Planet. 2008, Cheltenham, UK: Edward Elgar.

76. Gilek, M. and K. Kern, Governing Europe's Marine Environment. Europeanization of Regional Seas or Regionalization of EU Policies? 2015, London: Routledge.

77. Bertolt, W., Rational instrument or symbolic signal? Explaining coordination structures in the Directorate-General for Fisheries and Maritime Affairs of the European Commission. Public Policy and Administration, 2018. 33(2): p. 149-169. http://dx.doi.org/10.1177/0952076716683764

78. Olsen, E., et al., Integration at the round table: Marine spatial planning in multi-stakeholder settings. PLoS ONE, 2014. 9(10).

79. Calado, H., et al., NGO involvement in marine spatial planning: A way forward? Marine Policy, 2012. 36(2): p. 382-388. http://dx.doi.org/10.1016/i.marpol.2011.07.009

80. Österblom, H. and C. Folke, Emergence of global adaptive governance for stewardship of regional marine resources. Ecology and Society, 2013. 18(2). http://dx.doi.org/10.5751/ES$\underline{05373-180204}$

81. Biermann, F., et al., Earth system governance: A research framework. International Environmental Agreements: Politics, Law and Economics, 2010. 10(4): p. 277-298. http://dx.doi.org/10.1007/s10784-010-9137-3

82. Trouillet, B., Reinventing marine spatial planning: a critical review of initiatives worldwide. Journal of Environmental Policy \& Planning, 2020. 22(441-459). http://dx.doi.org/10.1080/1523908X.2020.1751605

83. Kirkfeldt, T.S., An ocean of concepts: Why choosing between ecosystem-based management, ecosystem-based approach and ecosystem approach makes a difference. Marine Policy, 2019. 106: p. 103541. http://dx.doi.org/https://doi.org/10.1016/j.marpol.2019.103541

84. Long, R.D., A. Charles, and R.L. Stephenson, Key principles of marine ecosystem-based management. Marine Policy, $2015 . \quad$ 57: p. 53-60. http://dx.doi.org/http://dx.doi.org/10.1016/j.marpol.2015.01.013

85. Waylen, K.A., et al., The Need to Disentangle Key Concepts from Ecosystem-Approach Jargon. Conservation Biology, 2014. 28(5): p. 1215-1224. http://dx.doi.org/10.1111/cobi.12331

86. Levin, P.S., et al., Integrated Ecosystem Assessments: Developing the Scientific Basis for Ecosystem-Based Management of the Ocean. PLOS Biology, 2009. 7(1): p. e1000014. http://dx.doi.org/10.1371/journal.pbio.1000014

87. Foley, M.M., et al., Guiding ecological principles for marine spatial planning. Marine Policy, 2010. 34(5): p. 955-966. http://dx.doi.org/10.1016/j.marpol.2010.02.001

88. Costanza, R., et al., Principles for sustainable governance of the oceans. Science, 1998. 281(5374): p. 198-199. http://dx.doi.org/10.1126/science.281.5374.198

89. Arkema, K.K., S.C. Abramson, and B.M. Dewsbury, Marine ecosystem-based management: From characterization to implementation. Frontiers in Ecology and the Environment, 2006. 4(10): p. 525-532. http://dx.doi.org/10.1890/1540-9295(2006)4[525:memfct]2.0.co;2 
90. Crowder, L.B., et al., Resolving mismatches in U.S. ocean governance. Science, 2006. 313(5787): p. 617-618. http://dx.doi.org/10.1126/science.1129706

91. Vierros, M., et al., Ecosystem approach and ocean management, in Ocean Sustainability in the 21st Century, S. Arico, Editor. 2015, CUP: Cambridge. p. 127-145. http://dx.doi.org/10.1017/CBO9781316164624.009

92. Kidd, S., et al., The Ecosystem Approach and Planning and Management of the Marine Envirnoment, in The ecosystem approach to marine planning and management, S. Kidd, A. Plater, and C. Frid, Editors. 2012. p. 1-33. http://dx.doi.org/10.4324/9781849775533

93. Kirk, E.A., The Ecosystem Approach and the Search for An Objective and Content for the Concept of Holistic Ocean Governance. Ocean Development and International Law, 2015. 46(1): p. 33-49. http://dx.doi.org/10.1080/00908320.2015.988938

94. Rodriguez, N.J.I., A comparative analysis of holistic marine management regimes and ecosystem approach in marine spatial planning in developed countries. Ocean and Coastal Management, 2017. 137: p. 185-197. http://dx.doi.org/10.1016/j.ocecoaman.2016.12.023

95. Douvere, F., The importance of marine spatial planning in advancing ecosystem-based sea use management. Marine Policy, 2008. 32(5): p. 762-771. http://dx.doi.org/10.1016/i.marpol.2008.03.021

96. Jones, P.J.S., L.M. Lieberknecht, and W. Qiu, Marine spatial planning in reality: Introduction to case studies and discussion of findings. Marine Policy, 2016. 71: p. 256-264. http://dx.doi.org/10.1016/i.marpol.2016.04.026

97. Hoel, A.H. and E. Olsen, Integrated Ocean Management as a Strategy to Meet Rapid Climate Change: The Norwegian Case. Ambio, 2012. 41(1): p. 85-95. http://dx.doi.org/10.1007/s13280-011-0229-2

98. Stojanovic, T. and R.C. Ballinger, Integrated Coastal Management: A Comparative Analysis of Four UK Initiatives. Applied Geography, 2009. 29(1): p. 49-62. http://dx.doi.org/doi:10.1016/j.apgeog.2008.07.005

99. Pitcher, T.J., et al., An evaluation of progress in implementing ecosystem-based management of fisheries in 33 countries. Marine Policy, 2009. 33(2): p. 223-232. http://dx.doi.org/10.1016/j.marpol.2008.06.002

100. Kidd, S., A. Plater, and C. Frid, The Ecosystem Approach to Marine Planning and Management. 2011: Taylor \& Francis.

101. Sander, G., Against all odds? Implementing a policy for ecosystem-based management of the Barents Sea. Ocean and Coastal Management, 2018. 157: p. 111-123. http://dx.doi.org/10.1016/i.ocecoaman.2018.01.020

102. Sander, G., Ecosystem-based management in Canada and Norway: The importance of political leadership and effective decision-making for implementation. Ocean and Coastal Management, 2018. 163: p. 485-497. http://dx.doi.org/10.1016/j.ocecoaman.2018.08.005

103. Barnes, R.A., Consolidating governance principles for areas beyond national jurisdiction. International Journal of Marine and Coastal Law, 2012. 27(2): p. 261-290. http://dx.doi.org/10.1163/157180812X633627

104. Bevir, M., ed. Sage Handbook of Governance. 2011, Sage: London.

105. Lockwood, M., Good governance for terrestrial protected areas: $A$ framework, principles and performance outcomes. Journal of Environmental Management, 2010. 91(3): p. 754-766. http://dx.doi.org/10.1016/i.jenvman.2009.10.005

106. Bennett, N.J. and T. Satterfield, Environmental governance: A practical framework to guide design, evaluation, and analysis. Conservation Letters, $2018.211(6)$. http://dx.doi.org/10.1111/conl.12600

107. Turner, R.A., et al., Measuring good governance for complex ecosystems: Perceptions of coral reef-dependent communities in the Caribbean. Global Environmental Change, 2014. 29(0): p. 105-117. http://dx.doi.org/http://dx.doi.org/10.1016/i.gloenvcha.2014.08.004 
108. Soma, K., J. van Tatenhove, and J. van Leeuwen, Marine Governance in a European context: Regionalization, integration and cooperation for ecosystem-based management. Ocean and Coastal Management, $2015 . \quad$ 117: $\quad$ p. $4-13$. http://dx.doi.org/10.1016/i.ocecoaman.2015.03.010

109. Morf, A., et al., Towards sustainability of marine governance: Challenges and enablers for stakeholder integration in transboundary marine spatial planning in the Baltic Sea. Ocean and Coastal Management, 2019. 177: 200-212. http://dx.doi.org/10.1016/j.ocecoaman.2019.04.009

110. Pinkerton, E. and L. John, Creating local management legitimacy. Marine Policy, 2008. 32(4): p. 680-691.

111. Griffin, L., The limits to good governance and the state of exception: A case study of North Sea fisheries. $\quad$ Geoforum, $2010 . \quad 41(2): \quad$ p. $282-292$. http://dx.doi.org/https://doi.org/10.1016/i.geoforum.2009.10.007

112. Henocque, Y. and B. Kalaora, Integrated Management of Seas and Coastal Areas in the Age of Globalization, in Governance of Seas and Oceans, A. Monaco and P. Prouzet, Editors. 2015, John Wiley \& Sons, Inc. p. 235-279. http://dx.doi.org/10.1002/9781119116233.ch7

113. Parris, T.M. and R.W. Kates, Characterizing and measuring sustainable development. Annual Review of Environment and Resources, 2003. 28: p. 559-586. http://dx.doi.org/10.1146/annurev.energy.28.050302.105551

114. Norris, P., Measuring Governance, in Sage Handbook of Governance, M. Bevir, Editor. 2011, Sage: London.

115. Ehler, C.N., Indicators to measure governance performance in integrated coastal management. Ocean and Coastal Management, 2003. 46(3-4): p. 335-345. http://dx.doi.org/10.1016/S0964-5691(03)00020-6

116. Cormier, R., et al., Marine Spatial Planning Quality Management System. ICES Cooperative Research Report No. 327. 2015.

117. Elliott, M., et al., "And DPSIR begat DAPSI(W)R(M)!" - A unifying framework for marine environmental management. Marine Pollution Bulletin, 2017. 118(1-2): p. 27-40. http://dx.doi.org/10.1016/j.marpolbul.2017.03.049

118. Olsen, S.B., G.G. Page, and E. Ochoa, The Analysis of Governance Responses to Ecosystem Change: A Handbook for Assessing a Baseline. 2009, LOICZ, GKSS Research Centre: Geesthacht.

119. Olsen, S.B., E. Olsen, and N. Schaefer, Governance baselines as a basis for adaptive marine spatial planning. Journal of Coastal Conservation, 2011. 15(2): p. 313-322. http://dx.doi.org/10.1007/s11852-011-0151-6

120. Olsen, S.B., J.H. McCann, and G. Fugate, The State of Rhode Island's pioneering marine spatial plan. Marine Policy, 2014. 45: p. 26-38. http://dx.doi.org/10.1016/j.marpol.2013.11.003

121. Economist Intelligence Unit, Coastal Governance Index. 2015.

122. Scott, K.N., The Evolution of Marine Spatial Planning in New Zealand: Past, Present and Possible Future. The International Journal of Marine and Coastal Law, 2016. 31(4): p. 652-689. http://dx.doi.org/10.1163/15718085-12341415

123. Collie, J.S., et al., Marine spatial planning in practice. Estuarine, Coastal and Shelf Science, 2013. 117: p. 1-11. http://dx.doi.org/10.1016/j.ecss.2012.11.010

124. Day, J., The need and practice of monitoring, evaluating and adapting marine planning and management-lessons from the Great Barrier Reef. Marine Policy, 2008. 32(5): p. 823-831. http://dx.doi.org/10.1016/j.marpol.2008.03.023

125. Pahl-Wostl, C., A conceptual framework for analysing adaptive capacity and multi-level learning processes in resource governance regimes. Global Environmental Change, 2009. 19(3): p. 354-365. http://dx.doi.org/https://doi.org/10.1016/j.gloenvcha.2009.06.001 
126. Pahl-Wostl, C., The role of governance modes and meta-governance in the transformation towards sustainable water governance. Environmental Science and Policy, 2019. 91: p. 6-16. http://dx.doi.org/10.1016/i.envsci.2018.10.008

127. Imperial, M.T., T.M. Hennesey, and D. Robadue, The Evolution of Adaptive Management for Esturine Ecosystems: the National Estuary Program and its Precursors. Ocean and Coastal Management, 1993. 20: p. 147-180.

128. Walters, C.J. and C.S. Holling, Large-scale management experiments and learning by doing. Ecology, 1990. 71(6): p. 2060-2068. http://dx.doi.org/10.2307/1938620

129. Mitchell, B., Integrated water resource management, institutional arrangements, and landuse planning. Environment and Planning A, 2005. 37(8): p. 1335-1352.

130. Howlett, M. and M. Ramesh, Achilles' heels of governance: Critical capacity deficits and their role in governance failures. Regulation and Governance, 2016. 10(4): p. 301-313. http://dx.doi.org/10.1111/rego.12091

131. Zervaki, A., The Ecosystem Approach in Ocean Planning and Governance, in The Ecosystem Approach and Public Engagement in Ocean Governance: The Case of Maritime Spatial $\begin{array}{lllll}\text { Planning. 2018, } & \text { Brill Nijhoff. } & \text { p. }\end{array}$ http://dx.doi.org/https://doi.org/10.1163/9789004389984009

132. Kearney, J., et al., The role of participatory governance and community-based management in integrated coastal and ocean management in Canada. Coastal Management, 2007. 35(1): p. 79-104.

133. Henry, A.D. and B. Vollan, Networks and the challenge of sustainable development. Annual Review of Environment and Resources, 2014. 39: p. 583-610. http://dx.doi.org/10.1146/annurev-environ-101813-013246

134. Bodin, Ö., Collaborative environmental governance: Achieving collective action in socialecological systems. Science, 2017. 357(6352).

135. Li, R., M. van den Brink, and J. Woltjer, Market-based instruments for the governance of coastal and marine ecosystem services: An analysis based on the Chinese case. Ecosystem Services, 2017. 23: p. 71-81. http://dx.doi.org/10.1016/i.ecoser.2016.11.018

136. Plummer, R., D.R. Armitage, and R.C. de Loë, Adaptive comanagement and its relationship to environmental Governance. Ecology and Society, 2013. 18(1). http://dx.doi.org/10.5751/ES05383-180121

137. Chaffin, B.C., H. Gosnell, and B.A. Cosens, A decade of adaptive governance scholarship: Synthesis and future directions. Ecology and Society, 2014. 19(3). http://dx.doi.org/10.5751/ES-06824-190356

138. Chaffin, B.C., et al., Transformative Environmental Governance. Annual Review of Environment and Resources, 2016. 41: p. 399-423. http://dx.doi.org/10.1146/annurevenviron-110615-085817

139. Kelly, C., G. Ellis, and W. Flannery, Conceptualising change in marine governance: Learning from Transition Management. Marine Policy, 2018. 95: p. 24-35. http://dx.doi.org/10.1016/i.marpol.2018.06.023

140. Rijke, J., et al., Configuring transformative governance to enhance resilient urban water systems. Environmental Science \& Policy, 2013. 25: p. 62-72. http://dx.doi.org/https://doi.org/10.1016/i.envsci.2012.09.012

141. Lemos, M.C. and A. Agrawal, Environmental governance. Annual Review of Environment and Resources, $2006 . \quad 31$ : 297-325. http://dx.doi.org/10.1146/annurev.energy.31.042605.135621

142. Jones, P.J.S., Governing Marine Protected Areas: resilience through diversity. 2014, London: Routledge Earthscan.

143. Scarff, G., C. Fitzsimmons, and T. Gray, The new mode of marine planning in the UK: Aspirations and challenges. Marine Policy, 2015. 51(0): p. 96-102. http://dx.doi.org/http://dx.doi.org/10.1016/j.marpol.2014.07.026 
144. Valman, M., H. ÖSterblom, and P. Olsson, Adaptive governance of the Baltic Sea - Lessons from elsewhere. International Journal of the Commons, 2015. 9(1): p. 440-465.

145. Tynkkynen, N., The challenge of environmental governance in the network society: The case of the Baltic Sea. Environmental Policy and Governance, 2013. 23(6): p. 395-406. http://dx.doi.org/10.1002/eet.1621

146. Hasselman, L., Adaptive management; adaptive co-management; adaptive governance: what's the difference? Australasian Journal of Environmental Management, 2017. 24(1): p. 3146. http://dx.doi.org/10.1080/14486563.2016.1251857

147. Blythe, J., et al., The Dark Side of Transformation: Latent Risks in Contemporary Sustainability Discourse. Antipode, 2018. 50(5): p. 1206-1223. http://dx.doi.org/10.1111/anti.12405

148. Glasbergen, P., Understanding partnerships for sustainable development analytically. The Ladder of Partnership Activity as a methodological tool. Environmental Policy and Governance, 2010. 21(1). http://dx.doi.org/10.1002/eet.545

149. Greenhill, L., T.A. Stojanovic, and P. Tett, Does marine planning enable progress towards adaptive governance of marine systems? Lessons from Scotland's regional marine planning process. Maritime Studies, 2020. https://doi.org/10.1007/s40152-020-00171-5

150. Bulkeley, H., Accomplishing climate governance. Accomplishing Climate Governance. 2015: $\begin{array}{lll}\text { Cambridge University 1-190. } & \end{array}$ http://dx.doi.org/https://doi.org/10.1017/СBO9781139839204

151. Leventon, J., Explaining implementation deficits through multi-level governance in the EU's new member states: EU limits for arsenic in drinking water in Hungary. Journal of Environmental Planning and Management, 2015. 58(7): p. 1137-1153. http://dx.doi.org/10.1080/09640568.2014.916611

152. Piattoni, S., The theory of multi-level governance: conceptual, empirical, and normative challenges. 2010, Oxford :: Oxford University Press. xiii, 301 p. ; $24 \mathrm{~cm}$. http://dx.doi.org/10.1093/acprof:oso/9780199562923.001.0001

153. Bulkeley, H., Reconfiguring environmental governance: Towards a politics of scales and networks. Political Geography, 2005. 24(8): p. 875-902. http://dx.doi.org/10.1016/j.polgeo.2005.07.002

154. Sievanen, L., R.L. Gruby, and L.M. Campbell, Fixing marine governance in Fiji? The new scalar narrative of ecosystem-based management. Global Environmental Change, 2013. 23(1): p. 206-216. http://dx.doi.org/10.1016/i.gloenvcha.2012.10.004

155. Degnbol, D. and D.C. Wilson, Spatial planning on the North Sea: A case of cross-scale linkages. Marine Policy, 2008. 32(2): p. 189-200. http://dx.doi.org/10.1016/i.marpol.2007.09.006

156. St. Martin, K. and M. Hall-Arber, The missing layer: Geo-technologies, communities, and implications for marine spatial planning. Marine Policy, 2008. 32(5): p. 779-786. http://dx.doi.org/10.1016/i.marpol.2008.03.015

157. Rosendo, S., et al., A clash of values and approaches: A case study of marine protected area planning in Mozambique. Ocean \& Coastal Management, 2011. 54(1): p. 55-65. http://dx.doi.org/https://doi.org/10.1016/j.ocecoaman.2010.10.009

158. Howlett, M., J. Vince, and P. Del Río, Policy integration and multi-level governance: Dealing with the vertical dimension of policy mix designs. Politics and Governance, 2017. 5(2): p. 6978. http://dx.doi.org/10.17645/pag.v5i2.928

159. van Tatenhove, J., J. van Leeuwen, and K. Soma, Marine governance as processes of regionalization: Conclusions from this special issue. Ocean and Coastal Management, 2015. 117: p. 70-74. http://dx.doi.org/10.1016/i.ocecoaman.2015.09.009

160. van Tatenhove, J.P.M., Transboundary marine spatial planning: a reflexive marine governance experiment? Journal of Environmental Policy and Planning, 2017: p. 1-12. http://dx.doi.org/10.1080/1523908X.2017.1292120 
161. Westholm, A., Appropriate scale and level in marine spatial planning - Management perspectives in the Baltic Sea. Marine Policy, 2018. 98: p. 264-270. http://dx.doi.org/https://doi.org/10.1016/j.marpol.2018.09.021

162. Suárez de Vivero, J.L., J.C. Rodríguez Mateos, and D. Florido del Corral, Geopolitical factors of maritime policies and marine spatial planning: State, regions, and geographical planning scope. Marine Policy, 2009. 33(4): p. 624-634.

163. Ritchie, H., Understanding emerging discourses of Marine Spatial Planning in the UK. Land Use Policy, $2014 . \quad 38: \quad$ p. $266-675$. http://dx.doi.org/http://dx.doi.org/10.1016/i.landusepol.2014.01.009

164. Silver, J.J., et al., Blue Economy and Competing Discourses in International Oceans Governance. Journal of Environment and Development, 2015. 24(2): p. 135-160. http://dx.doi.org/10.1177/1070496515580797

165. Voyer, M., et al., Shades of blue: what do competing interpretations of the Blue Economy mean for oceans governance? Journal of Environmental Policy and Planning, 2018. 20(5): p. 595616. http://dx.doi.org/10.1080/1523908X.2018.1473153

166. Merrie, A. and P. Olsson, An innovation and agency perspective on the emergence and spread of Marine Spatial Planning. Marine Policy, 2014. 44: p. 366-374. http://dx.doi.org/10.1016/i.marpol.2013.10.006

167. Olsen, S.B., Frameworks and Indicators for assessing progress in integrated coastal management initiatives. Ocean and Coastal Management, 2003. 46(3-4): p. 347-361.

168. Stojanovic, T.A., R.C. Ballinger, and C.S. Lalwani, Successful integrated coastal management: measuring it with research and contributing to wise practice. Ocean and Coastal Management, 2004. 47(5-6): p. 273-298. http://dx.doi.org/doi:10.1016/i.ocecoaman.2004.08.001

169. Ballinger, R., et al., An evaluation of the implementation of the European ICZM principles. Ocean \& Coastal Management, 2010. 53(12): p. 738-749. http://dx.doi.org/10.1016/j.ocecoaman.2010.10.013

170. Pittman, J. and D. Armitage, Governance across the land-sea interface: A systematic review. Environmental Science \& Policy, 2016. 64: p. 9-17. http://dx.doi.org/10.1016/i.envsci.2016.05.022

171. Karnauskaite, D., et al., Assessing coastal management case studies around Europe using an indicator based tool. Journal of Coastal Conservation, 2018. 22(3): p. 549-570. http://dx.doi.org/10.1007/s11852-018-0597-x

172. Van Assche, K., et al., Governance and the coastal condition: Towards new modes of observation, adaptation and integration. Marine Policy, 2020. 112: p. 103413. http://dx.doi.org/10.1016/j.marpol.2019.01.002

173. Söderström, S. and K. Kern, The Ecosystem Approach to Management in Marine Environmental Governance: Institutional interplay in the Baltic Sea Region. Environmental Policy and Governance, 2017. 27(6): p. 619-631. http://dx.doi.org/10.1002/eet.1775

174. Steinberg, P.E., It's so easy being green: Overuse, underexposure, and the marine environmentalist consensus. Geography Compass, 2008. 2(6): p. 2080-2096. http://dx.doi.org/10.1111/j.1749-8198.2008.00173.x

175. Jay, S., Marine Space: Manoeuvring Towards a Relational Understanding. Journal of Environmental Policy \& Planning, 2012. 14(1): p. 81-96. http://dx.doi.org/10.1080/1523908x.2012.662383

176. Boucquey, N., et al., The ontological politics of marine spatial planning: Assembling the ocean and shaping the capacities of 'Community' and 'Environment'. Geoforum, 2016. 75: p. 1-11. http://dx.doi.org/http://dx.doi.org/10.1016/i.geoforum.2016.06.014

177. Flannery, W., N. Healy, and M. Luna, Exclusion and non-participation in Marine Spatial Planning. Marine Policy, 2018. 88: p. 32-40. http://dx.doi.org/10.1016/j.marpol.2017.11.001 
178. Tafon, R.V., Taking power to sea: Towards a post-structuralist discourse theoretical critique of marine spatial planning. Environment and Planning C: Politics and Space, 2018. 36(2): p. 258273. http://dx.doi.org/doi:10.1177/2399654417707527

179. Ehler, C.N., A Guide to Evaluating Marine Spatial Plans, Paris, UNESCO. IOC Manuals and Guides, 70; ICAM Dossier 8. 2014.

180. Carneiro, G., Evaluation of marine spatial planning. Marine Policy, 2013. 37(1): p. 214-229. http://dx.doi.org/10.1016/j.marpol.2012.05.003

181. Slater, A.M. and J. Claydon, Marine Spatial Planning in the UK: A Review of the Progress and Effectiveness of the Plans and their Policies. Environmental Law Review, 2020. 22(2): p. 85107. https://doi.org/10.1177/1461452920927340

182. O'Neill, K., et al., Methods and Global Environmental Governance. Annual Review of Environment and Resources, 2013. 38(1): p. 441-471. http://dx.doi.org/doi:10.1146/annurevenviron-072811-114530

183. Young, O.R., et al., A portfolio approach to analyzing complex human-environment interactions: Institutions and land change. Ecology and Society, 2006. 11(2).

184. Cox, M., et al., Synthesizing theories of natural resource management and governance. Global Environmental Change, 2016. 39: p. 45-56. http://dx.doi.org/http://dx.doi.org/10.1016/i.gloenvcha.2016.04.011 